Article

\title{
The Impact of Spatiotemporal Changes in Land Development (1984-2019) on the Increase in the Runoff Coefficient in Erbil, Kurdistan Region of Iraq
}

\author{
Andam Mustafa *(D) and Michał Szydłowski ${ }^{(D)}$ \\ Faculty of Civil and Environmental Engineering, Gdańsk University of Technology, Narutowicza 11/12, \\ 80-233 Gdańsk, Poland; mszyd@pg.edu.pl \\ * Correspondence: andam.mustafa@pg.edu.pl; Tel.: +48-573-233-552
}

Received: 18 March 2020; Accepted: 18 April 2020; Published: 20 April 2020

\begin{abstract}
Nowadays, geospatial techniques are a popular approach for estimating urban flash floods by considering spatiotemporal changes in urban development. In this study, we investigated the impact of Land Use/Land Cover (LULC) changes on the hydrological response of the Erbil basin in the Kurdistan Region of Iraq (KRI). In the studied area, the LULC changes were calculated for 1984, 1994, 2004, 2014 and 2019 using the Digital Elevation Model (DEM) and satellite images. The analysis of LULC changes showed that the change between 1984 and 2004 was slower than that between 2004 and 2019. The LULC analysis revealed a 444.4\% growth in built-up areas, with a $60.4 \%$ decrease in agricultural land between 1984 and 2019. The influence of LULC on urban floods caused by different urbanization scenarios was ascertained using the HEC-GeoHMS and HEC-HMS models. Over 35 years, there was a 15\% increase in the peak discharge of outflow, from $392.2 \mathrm{~m}^{3} / \mathrm{s}$ in 1984 to $450 \mathrm{~m}^{3} / \mathrm{s}$ in 2014, as well as the runoff volume for a precipitation probability distribution of $10 \%$, which increased from $27.4 \mathrm{~mm}$ in 1984 to $30.9 \mathrm{~mm}$ in 2014 . Overall, the probability of flash floods increased in the center of the city due to the large expansion of built-up areas.
\end{abstract}

Keywords: remote sensing; LULC; maximum likelihood; image classification; urban flash floods; SCS-CN; hydrological modeling

\section{Introduction}

Since the last decades of the twentieth century, Remote Sensing (RS) has become a popular approach for detecting LULC changes. RS imagery has been universally applied in urban expansion and environmental analysis, with a large number of functional and sophisticated strategies being developed [1]. LULC classification plays an essential role in research on the physical and social sciences concerning urbanization and soil mapping [2]. LULC is an essential parameter for detecting human activities and natural changes due to climate change. LULC change detection is valuable for a broad variety of subjects, such as urban development, coastal dynamics, deforestation monitoring, shoreline changes and river transportation using multitemporal satellite images [3-5]. LULC changes are affected by human beings seeking to meet different needs, for instance, residential, agricultural, industrial, mining and other infrastructural facilities, and as such are main concerns connected with the economic and sustainable development of a region [6,7]. The timely and precise detection and identification of changes in the Earth's surface provide a foundation for a deeper understanding of human-nature interactions and correlations [8-13]. Formerly, in situ data had been used for studying LULC, although such kinds of data are inadequate in a spatial and temporal extent. It is also hard, if not impossible, to collect data from unreachable areas. Thus, data collection is drawn-out and often expensive. Therefore, such data are not dependable for effective planning and decision-making [14,15]. 
Satellite images are a valuable source of information on LULC as they provide swift, cyclic and precise data acquisition from the RS system [16]. Multitemporal RS data, mainly time-series Multispectral Scanner (MSS), Thematic Mapper (TM), Enhanced Thematic Mapper Plus (ETM+) and Landsat Data Continuity Mission (LDCM) images, have been extensively applied for detecting LULC changes since the launch of the Landsat satellite in the early 1970s [17-19]. The reason for the wide use of Landsat images by researchers is because they are relatively inexpensive, more accessible and have a long history.

The expansion of built-up areas is widely known as a means of establishing an unacceptable climate in terms of air quality and controlling natural resources. This is because urban sprawl is turning the natural land cover into man-made land cover to meet human needs [20]. Investigating spatial and temporal forms of urban development has become one of the most critical challenges in monitoring and analyzing present and future directions of urban growth issues [21]. Over the last 300 years, the global trend of LULC has been characterized by deforestation and the expansion of agricultural land [22]. However, during the last decades, developing countries have experienced a reduction in rural land and an expansion of urban areas through urbanization [23-26]. In many respects, urban growth phenomena have become unsustainable, in the majority of cities globally [27]. In fact, urbanization itself is a hot topic of concern globally, where people are leaving rural areas and settling in big cities [28].

The increase in impermeable areas in a catchment is known to boost flood risk [29]. Urbanization is considered to be the major cause of transformations in hydrologic and hydraulic processes, decreasing drainage capacity and increasing the number of flash floods in urban areas [30,31]. Consequently, it increases the total runoff volume and peak discharge of storm runoff events [23,32-36]. Therefore, it is essential and useful to understand to what degree, for what purpose, and at what place LULC changes occur. Such radical changes in LULC have drawn the attention of researchers more and more to determine the extreme effects of these transformations on several directions of urban planning and the environment, including strategic land management, air quality requirements, and the probability of decreasing flash floods [37-42]. Many papers have investigated the effects of LULC changes on urban flash floods. Sanyal et al. [34] regarding the Konar catchment in eastern India, showed that the increase in peak discharge for different LULC scenarios, like 1976 to 2004, was 1023.3 to $1194.7 \mathrm{~m}^{3} / \mathrm{s}$ with a shorter time to peak, at one hour and $10 \mathrm{~min}$. Al-Aysen, Riyadh, in Saudi Arabia, after a $15 \%$ increase in urbanization in the mentioned watershed, caused nearly a 30\% step-up in the peak discharge for the five-year return period event. An increase of $115 \%$ appeared when the basin became entirely urbanized for the five-year return period event [43]. Wałega et al. [29] determined the effect of catchment impermeability on flow variability in the Sudół Dominikański stream, Cracow, Poland and their investigation showed an increment in maximum flows over time connected to an increase in catchment imperviousness.

The KRI, from 2003 to present, witnessed its most significant development and expansion. The LULC patterns of Erbil, the capital city of the KRI, have changed extensively in the last two decades. These changes are because of the growth of the economy, and the region being comparatively safer than middle and southern Iraq. There is still a high demand for buying properties. Moreover, the Kurdistan Regional Government (KRG) encourages local and international investors to build residential and industrial areas. At the same time, the probability of the occurrence of urban flash floods in the center of Erbil Province is also increasing accordingly. Hameed, in his work that concerned the central district part of Erbil Province, showed that between 1984 and 2014, built-up areas and bare land expanded, while areas of vegetation and farmlands decreased dramatically [44]. Since 2010, the number of urban flash floods has increased, and as a consequence, many sewer pipes overflowed, which led to sewage escaping and mixing with stormwater. Flooding also caused more power outages as many local and small power generators were flooded [45].

During the last decades, the LULC of Erbil Province has significantly changed. Thus, the resulting changes need to be mapped urgently in order to recognize the direction of LULC transformation 
in the different parts of the city to assist in any possible land development planning, flood control and resource management. Assessing, identifying and classifying LULC changes in Erbil Province, and particularly how rapid urban development affects the center of the city, would contribute to managing the hydro-structures effectively and monitoring environmental changes. Additionally, it would help authorities in Erbil municipality and the General Directorate of Water and Sewerage to identify priorities, as well as helping them in making the right decisions. In this paper, we examined changes in LULC in the studied area in five phases. The time-steps started in 1984, 1994, 2004, 2014 and 2019. The studied area is located in Erbil-KRI (North of Iraq). We attempted to find answers to the four research questions concerning LULC changes and their influence on the runoff coefficient (the runoff coefficient is a unitless determinant that is used to convert the amounts of rainfall to runoff, or the ratio of the peak runoff rate to the rainfall intensity [46]) in the studied area from 1984 to 2019 :

(1) How was the LULC changed during this period, after every ten years?

(2) How did the economic, social and political situation affect the LULC changes?

(3) How did this transformation affect the hydrological response in the studied area?

(4) Is the probability of urban flash floods increasing?

\section{Materials and Methods}

\subsection{Study Area}

Erbil is a province located in the north of Iraq, and it is the capital city of the KRI. Erbil Province is considered to be the fourth biggest city in Iraq after Baghdad, Basra and Mosul. It lies approximately $350 \mathrm{~km}$ (220 miles) from Baghdad, the capital of Iraq. The total area of Erbil Province is $14,873.68 \mathrm{~km}^{2}$; however, the area considered as the studied area in this work is $508.074 \mathrm{~km}^{2}$ (Figure 1). The studied area is delineated based on the hydrological situation, using HEC-GeoHMS in ArcGIS 10.5.1, which affects the center of the city in terms of runoff during precipitation events. Due to the location of Erbil Province, it has a semi-arid continental climate and is characterized by hot and dry summers and cold and wet winters. The mean annual precipitation in the central district of Erbil Province from 1980 to 2018 was $419.2 \mathrm{~mm}$. Moreover, the maximum annual rainfall in 1992 reached $866.3 \mathrm{~mm}$, and the minimum in 1999 was $225.8 \mathrm{~mm}$ [47].

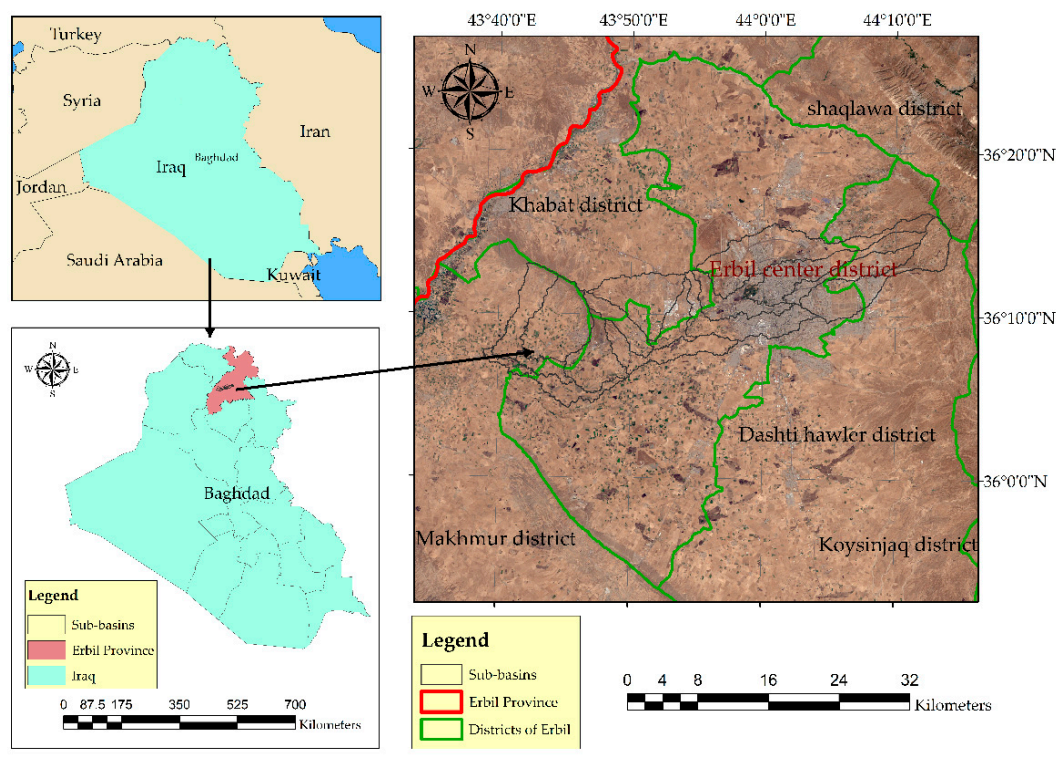

Figure 1. Study area.

Erbil is going through essential changes because of the impact of political, economic, global, cultural and demographic transformations. The independent management of resources and revenues 
hand-in-hand with economic prosperity allowed the city to speed up its reconstruction and development, with the benefit of more stability and a safer environment compared to other cities in the center and south of Iraq [48,49]. After several political upheavals and demographic changes in the region, Erbil Province stands as a durable model of exponential urban development, for instance, recently, following the ISIS attack on Syria and Iraq, from 2013 to 2019. In Iraq, the attack targeted the Sunnis zones in the center and mid-west of Iraq as well as the Yazidis area in the Sinjar district, forcing thousands of civilians to flee their homes to the KRI, especially Erbil and Duhok. At that time, the international community, Internal Displaced People (IDP) and refugee organizations built shelters and temporary camps for those people who relocated from their homelands. This demographic change is one of the tens of political upheavals in the region.

\subsection{Workflow}

The methodology applied in this study is illustrated in Figure 2. The expected outcomes are the LULC scenarios for 1984, 1994, 2004, 2014 and 2019. Furthermore, their influence on the hydrological response. To reach these targets, several steps were taken. First, we collected the required data for the study, such as remote sensing data, rainfall datasets and soil maps. Second, we started with image analyses using supervised classification; we used the maximum likelihood classification to extract LULC maps from Landsat images. In the third step, unifying both the LULC maps and soil maps in ArcMap using the HEC-GeoHMS tool, a CN grid was prepared. Moreover, we calculated the basin characteristics and basin slope using DEMs. Lastly, we simulated the hydrological model in HEC-HMS, in order to compare different scenarios and assess the transformation and development in the studied area. In the following sub-sections, the methodology is described in detail.

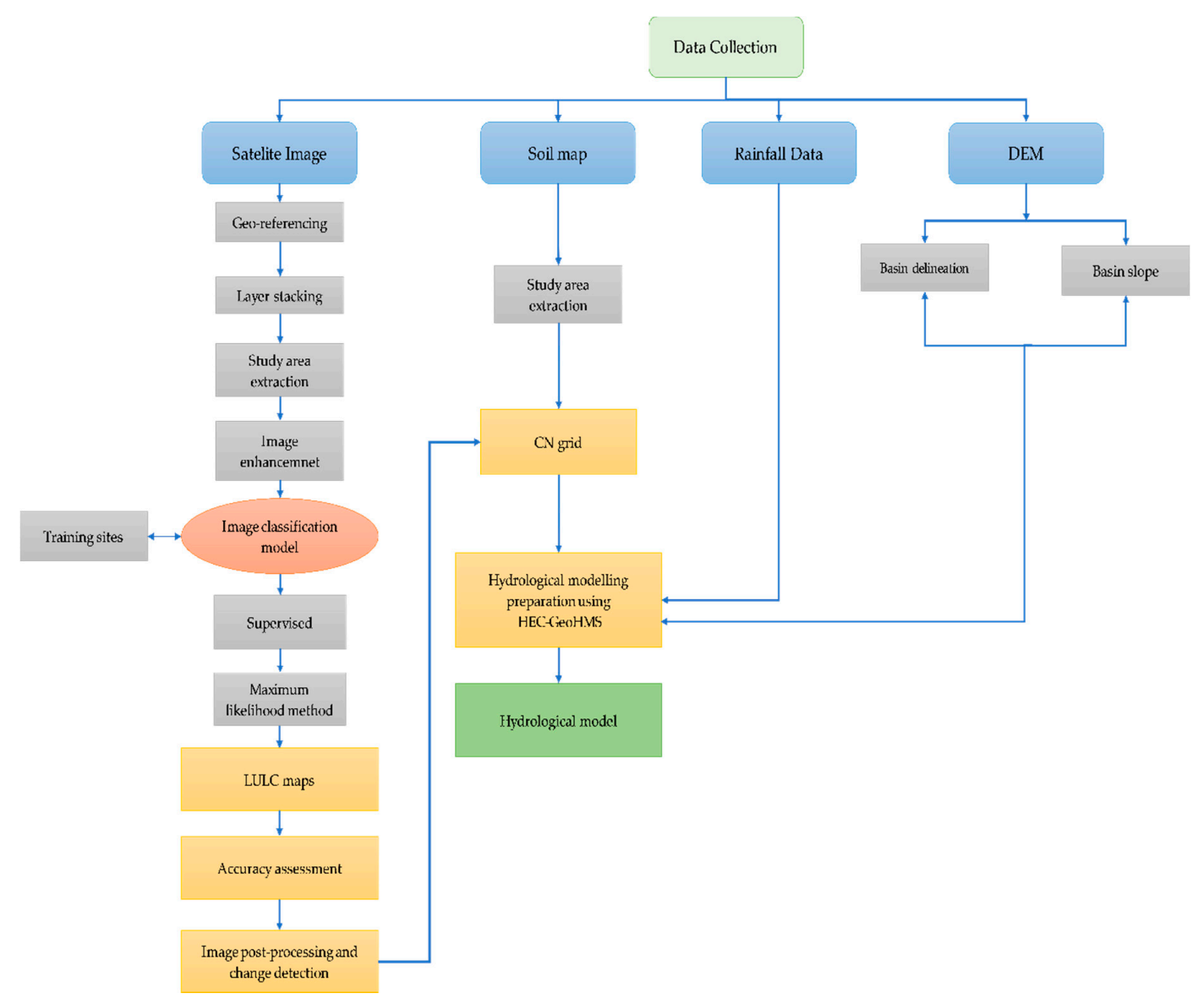

Figure 2. Flow chart of the applied methodology in the study. 


\subsection{Remote Sensing Data Acquisition}

To examine the LULC changes in the center of Erbil Province, different LULC cover types were prepared from remotely sensed data. Satellite images from Landsat 4-5 TM (1982-2011), Landsat 7 ETM+ (1999-present) and Landsat 8 OLI (2013-present) were downloaded from the LandsatLook viewer (https://landsatlook.usgs.gov/viewer.html). The images were taken by the satellite on different dates, as listed in Table 1. The images were selected based on quality, especially those images which were free of cloud or had a limited rate. Moreover, images were selected nearly in the same season, between June and August, in order to have a similar seasonal variation of LULC. In addition, the DEM of the Shuttle Radar Topography Mission (SRTM) (http://dwtkns.com/srtm30m/) was acquired at 1 arc-second $(30 \mathrm{~m})$ resolution, to delineate the watershed boundary of the studied area. Furthermore, higher spatial resolution true-color satellite and aerial imagery were retrieved from Google Maps and HERE WeGo (wego.here.com). A soil map of the studied area was extracted using a basin boundary from the prepared digital soil map of Iraq by the Food and Agriculture Organization (FAO) (Figure 3).

Table 1. Source and details of Landsat images used for classification.

\begin{tabular}{|c|c|c|c|c|c|}
\hline Satellite & Sensor_ID & Path/Row & $\begin{array}{c}\text { No. } \\
\text { Bands }\end{array}$ & $\begin{array}{c}\text { Date of } \\
\text { Acquisition }\end{array}$ & $\begin{array}{l}\text { Grid Cell } \\
\text { Size }(\mathrm{m})\end{array}$ \\
\hline $\begin{array}{c}\text { Landsat 4-5 TM C1 } \\
\text { Level-1 }\end{array}$ & LT51690351984167XXX02 & $169 / 35$ & 7 & 15 June 1984 & 30 \\
\hline $\begin{array}{c}\text { Landsat 4-5 TM C1 } \\
\text { Level-1 }\end{array}$ & LT51690351994226RSA00 & $169 / 35$ & 7 & 14 August 1994 & 30 \\
\hline $\begin{array}{c}\text { Landsat } 7 \text { ETM+ C1 } \\
\text { Level-1 }\end{array}$ & LE71690352004198ASN01 & $169 / 35$ & 9 & 16 July 2004 & 30 \\
\hline $\begin{array}{c}\text { Landsat } 8 \text { OLI/TIRS C1 } \\
\text { Level-1 }\end{array}$ & LC81690352014201LGN01 & $169 / 35$ & 11 & 20 July 2014 & 30 \\
\hline $\begin{array}{c}\text { Landsat } 8 \text { OLI/TIRS C1 } \\
\text { Level-1 }\end{array}$ & LC81690352019183LGN00 & $169 / 35$ & 11 & 2 July 2019 & 30 \\
\hline
\end{tabular}

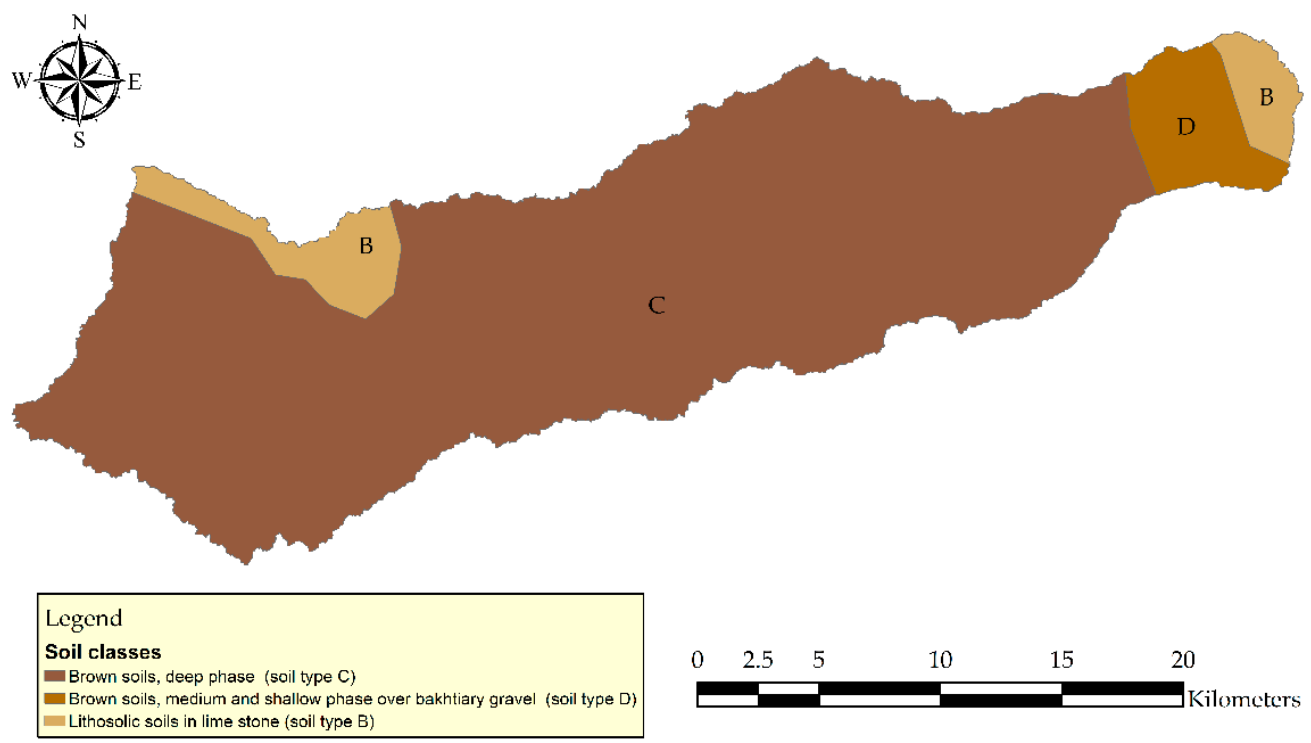

Figure 3. The soil classes in the study area.

\subsection{Image Pre-Processing}

Extensive pre-processing was done, particularly geo-referencing, layer stacking, extraction and image enhancement. Layers were stacked using Edras Imagine 2014 in order to obtain multi-composite images for further processing, and then from the stacked satellite image, the study area was extracted with "extract by mask" using the Erbil basin boundary prepared in ArcGIS 10.5.1, and again, using 
Edras Imagine 2014, the resolution of the images was enhanced twice using the convolution function in spatial tools and the subset function in subset and chip tools. The enhancement process was carried out in order to obtain a clear image for the classification and accuracy assessment stage.

\subsection{Image Classification}

Image classification and change identification are two of the most common techniques for observing LULC changes in urban areas. The process is complex and requires the consideration of several factors, and it should be done accurately. Concerning the LULC classification, the basin was categorized into five different classes: water (including rivers, tributaries and ponds), built-up (including residential, industrial, commercial, local streets, roads and other urban areas), bare land (uncovered soils, unused areas, rocky mountains and dry river beds), agriculture (including crop fields and fallow areas) and finally vegetation (including forests, orchards, vegetable fields, parks, lawns, shrubs and others). For this study, supervised classification was performed using Edras Imagine 2014. Supervised classification is where the software user creates spectral signatures of known classes, such as urban, water and agriculture, and then the software specifies each pixel in the image to the cover type to which its signature is most comparable [50]. The maximum likelihood classifier (MLC) is one of the most popular adopted parametric classification algorithms [12,51-54]. At the beginning of the classification process, three bands were combined as a false-color composite, including band nos. 5, 4 and 3, for each LULC class in each satellite image, 20 training sites were collected. In total, 100 training sites were collected for one image. With this background, 500 training sites have been collected for five satellite images. During this process, Google Maps and HERE WeGo (wego.here.com) were used with the aim of obtaining an accurate definition of the training sites. The training sites were different in pixel size and used as an area of interest to train the images, to be later merged into one signature for a given LULC category and used for the classification.

\subsection{Image Post-Processing}

The LULC maps were noisy as a consequence of the resemblances of the spectral responses of specific land cover classes such as pasture/scrubland and built-up areas. In this process, the classified image was accurately compared to reality, and an accuracy assessment analysis was performed to verify the classification results. The purpose of the accuracy assessment was to quantitatively evaluate how or to what effective degree the pixels were sampled into the LULC categories. The accuracy of the classified images from 1984, 1994, 2004, 2014 and 2019 was evaluated by Edras Imagine 2014 using randomly generated points. Some studies used 500 reference points for accuracy assessment $[55,56]$, however number of reference points depends on the size of the studied area. In this study for each image, 500 reference points were generated (equalized random points per class) and aligned to the boundary of the study area shapefile. This was necessary to assess the accuracy of the classification results and the modification of land cover categories.

\subsection{Hydrological Modeling Using HEC-HMS}

The Hydrologic Engineering Center-Hydrologic Modeling System (HEC-HMS) was developed to simulate the precipitation-runoff procedures of dendritic watershed systems [57]. The model consists of multi sub-models to simulate different elements of the runoff formation process with the choice of various infiltrations, unit hydrographs and flood routing methods. Because of its simplicity and the limited number of parameters, HEC-HMS is universally used, which makes calibration relatively uncomplicated [36]. The basin model, meteorological model and control specification are the three main models of simulation in HEC-HMS [32]. The basin model, consisting of the delineation of sub-basins, sub-basin areas, river length, river slope, longest flow path, elevation and basin slope, was developed using HEC-GeoHMS [58], and the said basin model was then converted to the HEC-HMS model (Figure 4). The Soil Conservation Service (SCS) Curve Number (CN) (today, the Natural Resources Conservation Service (NRCS)) method was applied for precipitation losses. Many studies showed that 
the $\mathrm{CN}$ method could be applied in different environments and, despite its simplicity, can produce practicable results comparable to those of more complicated models $[59,60]$. The SCS-Unit hydrograph method was applied for transformation, and the Muskingum-Cunge method was used for river routing. Analyzed long-term series of maximum daily rainfall data were used in this study and within them, a probability distribution of $10 \%$, which is equal to $71.16 \mathrm{~mm}$ [47].

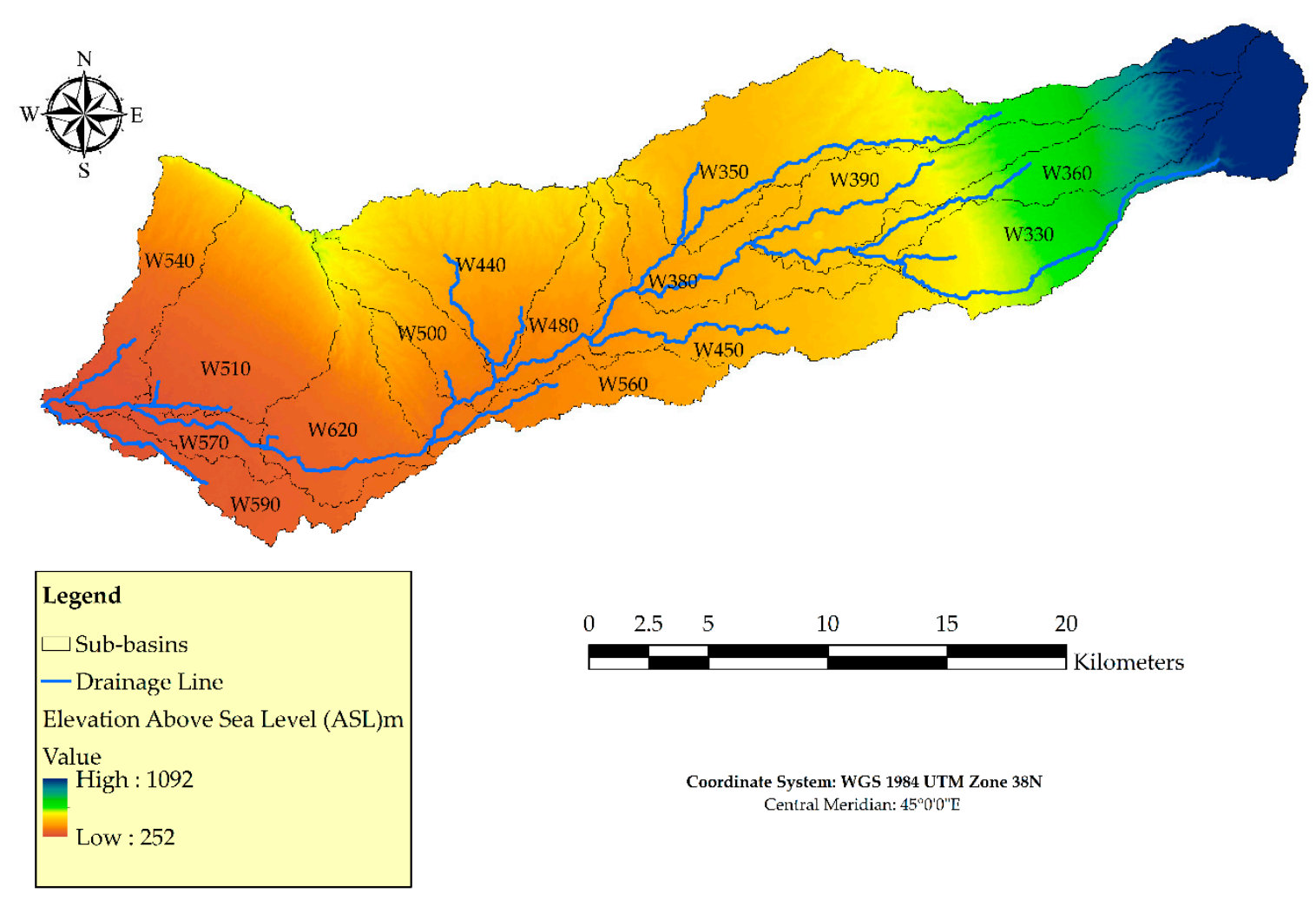

Figure 4. Topography and delineated sub-basins over the study area.

\section{Results}

\subsection{LULC Accuracy Assessment}

The classification accuracy of the prepared LULC change maps was evaluated. The producer's accuracy is the number of correctly classified reference points of a particular class divided by the total number of reference points for that category. It is an indicator of the error of omission [61]. The user's accuracy is an alternative measure for individual category accuracy. It is the number of correctly classified reference points of a specific class divided by the total number of points being classified as that category. It measures the error of commission [62]. The accuracy assessment for the results of five images showed an overall classification accuracy of $85.60 \%$. While each image was analyzed and assessed independently, as in this study, different satellite images were used (Table 2). The accuracy rate depends on the quality of RS data such as the resolution, available bands and the quality of the image. In this study, there is a limitation to examine the accuracy of classified maps because of the nature of LULC changes, which alter according to different regional conditions, and also due to the lack of availability of ground values.

\subsection{LULC Results and Change Detection}

The resulting LULC maps generated for the studied area for 1984, 1994, 2004, 2014 and 2019 are shown in Figure 5a-e, respectively. 
Table 2. Accuracy assessment for the 1984, 1994, 2004, 2014 and 2019 classified images based on the error matrix.

\begin{tabular}{|c|c|c|c|c|c|c|}
\hline & Years & Water & Built-up & Bare Land & Agriculture & Vegetation \\
\hline Producer's Accuracy (\%) & \multirow{2}{*}{1984} & 100 & 98.88 & 62.99 & 78.69 & 94.74 \\
\hline User's Accuracy (\%) & & 86.00 & 88.00 & 80.00 & 96.00 & 72.00 \\
\hline \multicolumn{5}{|c|}{ Overall Classification Accuracy (\%) } & 84.40 & \\
\hline \multicolumn{5}{|c|}{ Kappa Statistics (\%) } & 80.50 & \\
\hline Producer's Accuracy (\%) & & 100 & 98.80 & 57.25 & 80.70 & 97.73 \\
\hline User's Accuracy (\%) & 1994 & 77.00 & 82.00 & 79.00 & 92.00 & 86.00 \\
\hline \multicolumn{5}{|c|}{ Overall classification Accuracy (\%) } & 83.20 & \\
\hline \multicolumn{5}{|c|}{ Kappa Statistics (\%) } & 79.00 & \\
\hline Producer's Accuracy (\%) & & - & 99.04 & 68.21 & 81.02 & 99.07 \\
\hline User's Accuracy (\%) & 2004 & - & 82.40 & 82.40 & 88.80 & 85.60 \\
\hline \multicolumn{5}{|c|}{ Overall Classification Accuracy (\%) } & 84.80 & \\
\hline \multicolumn{5}{|c|}{ Kappa Statistics (\%) } & 79.73 & \\
\hline Producer's Accuracy (\%) & & - & 95.28 & 83.85 & 77.78 & 93.69 \\
\hline User's Accuracy (\%) & 2014 & - & 80.80 & 87.20 & 95.20 & 83.20 \\
\hline \multicolumn{5}{|c|}{ Overall Classification Accuracy (\%) } & 86.60 & \\
\hline \multicolumn{5}{|c|}{ Kappa Statistics (\%) } & 82.13 & \\
\hline Producer's Accuracy (\%) & & - & 95.37 & 83.21 & 84.83 & 95.45 \\
\hline User's Accuracy (\%) & 2019 & - & 82.40 & 91.20 & 98.40 & 84.00 \\
\hline \multicolumn{5}{|c|}{ Overall Classification Accuracy (\%) } & 89.00 & \\
\hline \multicolumn{4}{|c|}{ Kappa Statistics (\%) } & & 85.33 & \\
\hline
\end{tabular}
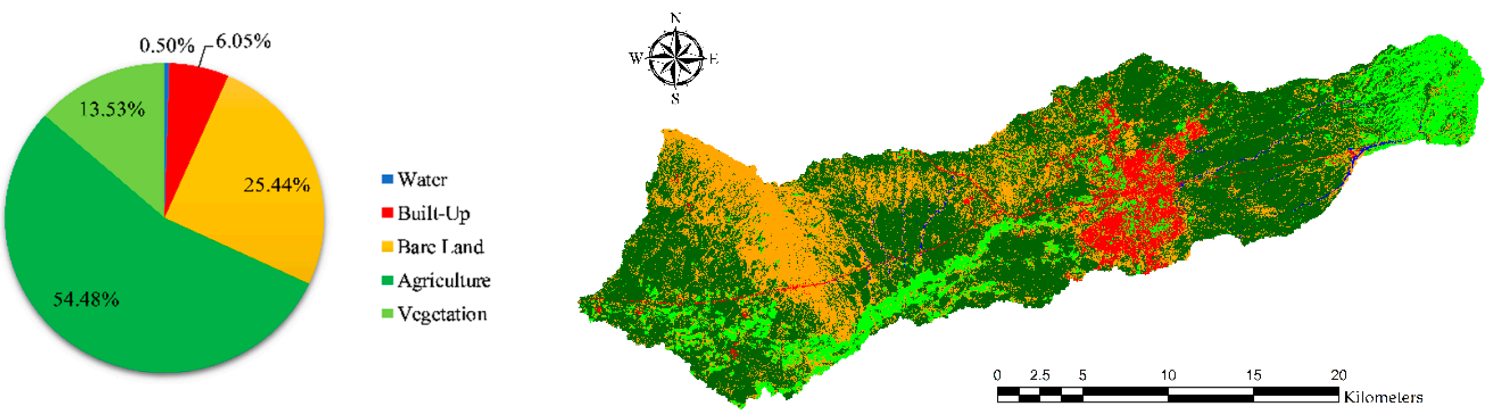

(a) 1984
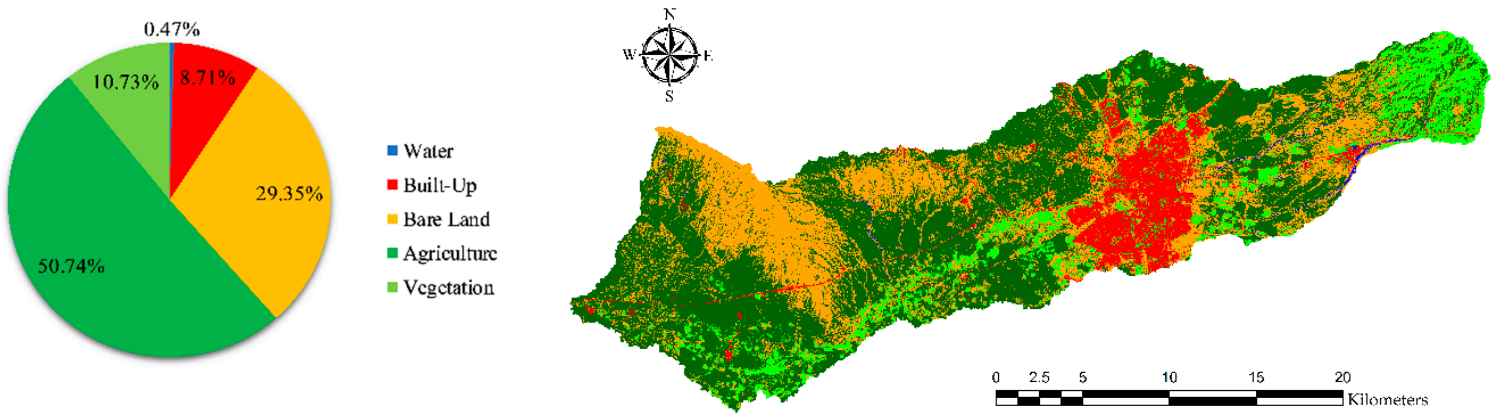

(b) 1994

Figure 5. Cont. 

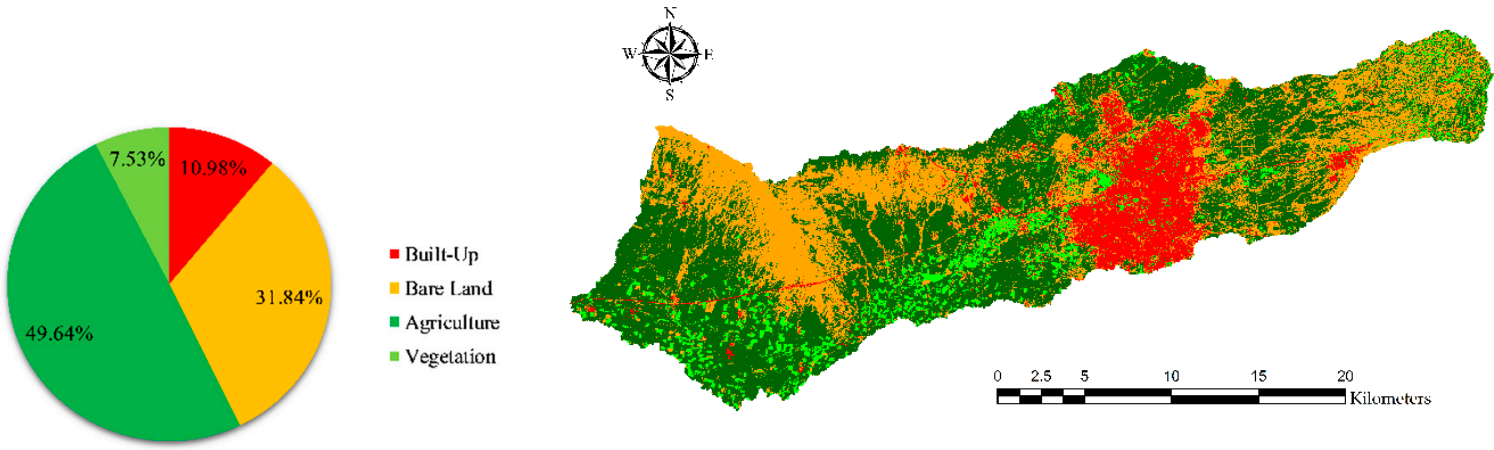

(c) 2004
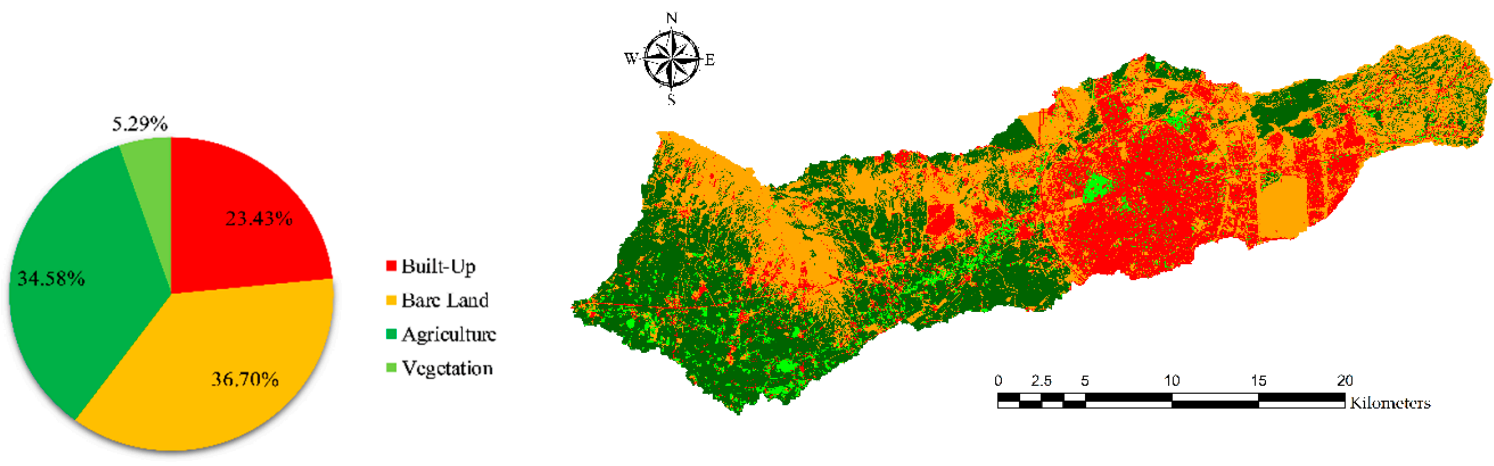

(d) 2014

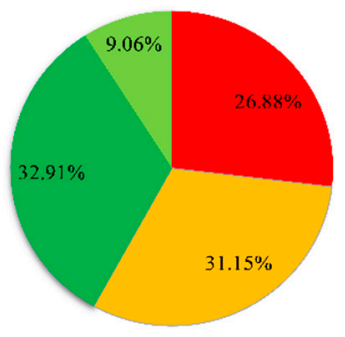

- Buill--I/p
- Bare Land
- Agriculture
- Vegelation

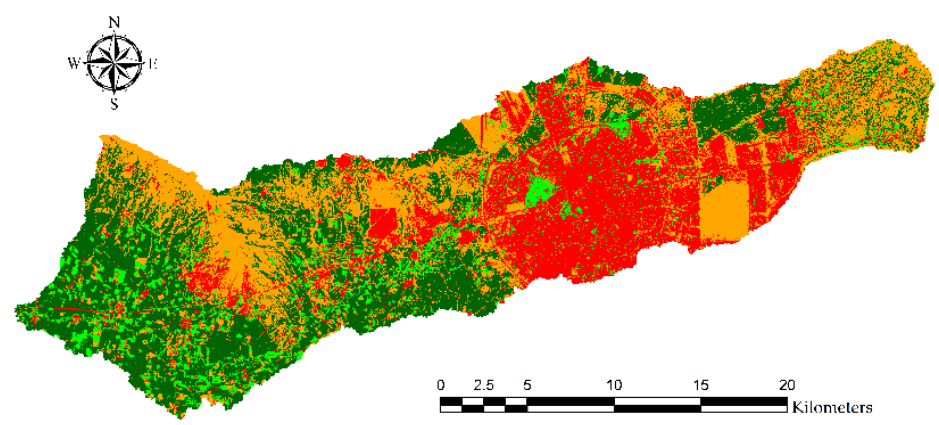

(e) 2019

Figure 5. Land Use/Land Cover (LULC) maps of the studied area for the years (a) 1984, (b) 1994, (c) 2004, (d) 2014 and (e) 2019.

The water class was only about $0.50 \%$ in 1984 and 1994, and after this period surface waters disappeared in the basin. Nevertheless, surface waters flow in seasonal streams if there is enough precipitation in the year. For example, in 2018, annual precipitation reached $721.3 \mathrm{~mm}$, and this amount was not recorded in Erbil city center from 1992. As a consequence of this, some seasonal streams appeared again. In 1984, 1994 and 2004, built-up areas steadily increased, starting from $30.751 \mathrm{~km}^{2}$ to 44.283 and then to 55.823, respectively (Figure 5). While in 2014, this amount leaped enormously to about $119.101 \mathrm{~km}^{2}$. From 1984 to 2014 , the areas of agriculture and vegetation decreased significantly. For instance, agricultural areas in 1984 were 54\% of the total area but this range in 2019 decreased to about 33\%, and the range of vegetation also decreased from about 14\% in 1984 to just 5\% in 2014 . The results, as mentioned earlier, revealed that there is a steady transformation in the LULC from 1984 to 2004 compared with that between 2004 and 2014. Impactful LULC changes, and ultimately, 
development in the urban area, were observed in the studied area from 2004 to the present. In 2019, built-up areas reached $136.658 \mathrm{~km}^{2}$, and bare land, compared to 2014, was reduced. In contrast to the decreasing trend of the previous decades, starting from 68.756 to 54.568 and 38.298 , and then to $26.893 \mathrm{~km}^{2}$, in 2019 the area of vegetation increased to about $46.054 \mathrm{~km}^{2}$ (Table 3).

Table 3. LULC categories; their corresponding areas for 1984, 1994, 2004, 2014 and 2019.

\begin{tabular}{cccccc}
\hline LULC & $\mathbf{1 9 8 4}$ & $\mathbf{1 9 9 4}$ & $\mathbf{2 0 0 4}$ & $\mathbf{2 0 1 4}$ & $\mathbf{2 0 1 9}$ \\
\cline { 2 - 6 } Category & \multicolumn{5}{c}{ Area $\mathbf{( \mathbf { k m } ^ { \mathbf { 2 } } )}$} \\
\hline Water & 2.537 & 2.387 & - & - & - \\
Built-up & 30.751 & 44.283 & 55.823 & 119.101 & 136.658 \\
Bare land & 129.337 & 149.191 & 161.863 & 186.572 & 158.347 \\
Agriculture & 276.966 & 257.919 & 252.363 & 175.781 & 167.288 \\
Vegetation & 68.756 & 54.568 & 38.298 & 26.893 & 46.054 \\
\hline
\end{tabular}

\subsection{Influence of Urbanization on the Flash Flood Potential}

The present study is focused on both urban development and its impact on the flood peak discharge, as well as the runoff coefficient and the flood hydrograph, using the rainfall-runoff hydrological modeling for a storm rainfall depth with the probability distribution of $10 \%$, which is equal to $71.16 \mathrm{~mm}$, and the land use conditions of 1984, 1994, 2004, 2014 and 2019. The SCS-CN loss method has been applied in the HEC-HMS model for computing the runoff. The soil group, land use and hydrological condition of the land cover are the main factors in calculating the CN. The LULC and soil maps are unified, and the hydrological soil group was set as per the soil cover. The assigned $\mathrm{CN}$, relevant to the hydrological soil group and land use cover, is tabulated in Table 4 . The composite $\mathrm{CN}$ for each sub-basin was derived and used as the input for the SCS-CN modeling in HEC-HMS (Table 5).

Table 4. Runoff curve number for the integration of different land cover and hydrological soil groups.

\begin{tabular}{ccccc}
\hline \multirow{2}{*}{ LULC Category } & \multicolumn{5}{c}{ Runoff Curve Number for Different Soil Groups } \\
\cline { 2 - 5 } & A & B & C & D \\
\hline Water & 100 & 100 & 100 & 100 \\
Built Up & 77 & 85 & 90 & 92 \\
Bare Land & 68 & 79 & 86 & 89 \\
Agriculture & 65 & 76 & 84 & 88 \\
Vegetation & 43 & 65 & 76 & 82 \\
\hline
\end{tabular}

The hydrological modeling reveals that flash flooding caused by more frequent rainfall events (with a smaller probability distribution $[47,63]$ ) is increased more by urban growth than by large storm events. Erbil is undergoing an observable horizontal expansion. It has been developing in all directions due to its location on flat terrain and the form and height of Erbil Citadel, which have shaped the urban model of the peripheral areas as concentric rings with a radial axis [48]. A large number of land parcels were distributed within the city master plan, but some of these distributed lands lack municipal services and facilities, and have therefore remained undeveloped [48]. Nevertheless, the category of the land has changed, for instance, from agricultural land to residential land, for example, a neighborhood called Hasarok 8, which was distributed more than fifteen years ago. Generally, the residential areas are more concentrated on the east, north-east and south-east of the city. Hence, the mentioned areas are among the most populated. While the other part of the city is more developed regarding architecture and urban design trends. Wealthy quarters and exclusive compounds have been established, along with several office buildings and business centers [48]. Nowadays, Erbil is considered to be the region's most developed city and it is a powerful economy for several reasons, such as: being the capital of the KRI, and the existence of KRG ministries, the parliament, international organizations (UN, UNHCR, UNDP, NRC, AMG, etc.), the airport, diplomatic representatives, international companies and the 
newly generated and expanded political infrastructure. At present, Erbil has more than ninety different quarters, in comparison to eighty-two in 2012, and in 1950 only eight [64]. This can be noticed more visibly in the upper sub-basins (W330, W350, W360, W380, W390 and W450) (Table 6), where there is a dramatic increase in built-up areas, especially in W330 which grew by about 2178\% between 2004 and 2019. Also, built-up areas in sub-basins such as W350 and W360 grew by 465.14\% and 1029.29\%, respectively. However, there was also development in the built-up areas in the lower sub-basins (440, 480 and 500, 510, 540, 560, 570, 590 and 620). Generally, a lower sub-basin is considered as a rural agricultural area. Between 1984 and 2004, development in these areas was slow. Then after 2004, development started in these areas but the development could not be compared in size to the upper sub-basins.

Table 5. Calculated runoff curve number based on the unified soil groups layer and LULC layer of the sub-basins in the studied area using HEC-GeoHMS.

\begin{tabular}{cccccc}
\hline \multirow{2}{*}{ Sub-Basins } & \multicolumn{5}{c}{ Years } \\
\cline { 2 - 5 } & $\mathbf{1 9 8 4}$ & $\mathbf{1 9 9 4}$ & $\mathbf{2 0 0 4}$ & $\mathbf{2 0 1 4}$ & $\mathbf{2 0 1 9}$ \\
\hline W330 & 81.12 & 81.81 & 83.74 & 86.14 & 86.15 \\
W350 & 83.89 & 83.99 & 84.57 & 86.07 & 86.10 \\
W360 & 84.39 & 85.58 & 86.15 & 87.74 & 87.84 \\
W380 & 84.84 & 85.26 & 85.62 & 87.02 & 86.96 \\
W390 & 85.03 & 86.31 & 87.07 & 87.52 & 87.44 \\
W440 & 83.49 & 83.53 & 83.68 & 84.06 & 83.83 \\
W450 & 84.92 & 85.15 & 85.70 & 87.21 & 87.20 \\
W480 & 82.95 & 83.71 & 83.44 & 85.01 & 85.23 \\
W500 & 82.21 & 82.28 & 82.17 & 82.68 & 82.44 \\
W510 & 84.20 & 84.38 & 84.18 & 84.39 & 83.79 \\
W540 & 83.55 & 83.64 & 83.51 & 83.73 & 83.19 \\
W560 & 83.10 & 83.71 & 83.47 & 84.52 & 84.21 \\
W570 & 82.37 & 83.44 & 83.12 & 83.59 & 82.83 \\
W590 & 82.75 & 82.97 & 82.79 & 83.18 & 82.93 \\
W620 & 83.21 & 83.89 & 83.82 & 84.32 & 83.96 \\
\hline
\end{tabular}

Table 6. LULC changes in the studied area in each sub-basin with changes between 1984-2004 and 2004-2019.

\begin{tabular}{|c|c|c|c|c|c|c|c|c|}
\hline \multirow{2}{*}{ Sub-Basin } & \multirow{2}{*}{ LULC } & \multicolumn{5}{|c|}{ Area $\left(\mathrm{km}^{2}\right)$} & \multicolumn{2}{|c|}{ (\%) Change in LULC } \\
\hline & & 1984 & 1994 & 2004 & 2014 & 2019 & 1984-2004 & 2004-2019 \\
\hline \multirow{5}{*}{ W330 } & Water & 0.854 & 1.025 & - & - & - & -100 & - \\
\hline & Built-up & 0.762 & 2.206 & 2.696 & 16.932 & 19.301 & +253.72 & +2178.28 \\
\hline & Bare Land & 5.843 & 14.292 & 21.413 & 29.678 & 25.958 & +266.48 & +77.79 \\
\hline & Agriculture & 29.296 & 20.035 & 24.719 & 4.972 & 5.155 & -15.62 & -66.78 \\
\hline & Vegetation & 16.323 & 15.521 & 4.251 & 1.498 & 2.664 & -73.96 & -9.72 \\
\hline \multicolumn{2}{|c|}{ Total Area $\left(\mathrm{km}^{2}\right)$} & & & 53.078 & & & & \\
\hline \multirow{5}{*}{ W350 } & Water & 0.036 & 0.002 & - & - & - & -100 & - \\
\hline & Built-up & 3.333 & 4.163 & 5.681 & 16.387 & 21.182 & +70.46 & +465.14 \\
\hline & Bare Land & 12.965 & 12.467 & 19.114 & 33.339 & 25.371 & +47.43 & +48.26 \\
\hline & Agriculture & 46.222 & 46.396 & 40.575 & 17.280 & 18.666 & -12.22 & -47.40 \\
\hline & Vegetation & 7.542 & 7.070 & 4.728 & 3.092 & 4.878 & -37.32 & +1.99 \\
\hline \multicolumn{2}{|c|}{ Total Area $\left(\mathrm{km}^{2}\right)$} & & & 70.097 & & & & \\
\hline \multirow{5}{*}{ W360 } & Water & 0.553 & 0.597 & - & - & - & -100 & - \\
\hline & Built-up & 0.919 & 2.619 & 3.584 & 10.787 & 13.042 & +290.01 & +1029.29 \\
\hline & Bare Land & 3.468 & 11.200 & 12.087 & 11.249 & 7.593 & +248.56 & -129.59 \\
\hline & Agriculture & 16.694 & 7.953 & 9.266 & 2.977 & 3.677 & -44.50 & -33.48 \\
\hline & Vegetation & 4.079 & 3.344 & 0.776 & 0.699 & 1.400 & -80.98 & +15.31 \\
\hline
\end{tabular}


Table 6. Cont

\begin{tabular}{|c|c|c|c|c|c|c|c|c|}
\hline \multirow{2}{*}{ Sub-Basir } & \multirow{2}{*}{ LULC } & \multicolumn{5}{|c|}{ Area $\left(\mathrm{km}^{2}\right)$} & \multicolumn{2}{|c|}{ (\%) Change in LULC } \\
\hline & & 1984 & 1994 & 2004 & 2014 & 2019 & 1984-2004 & 2004-2019 \\
\hline \multicolumn{2}{|c|}{ Total Area $\left(\mathrm{km}^{2}\right)$} & & & 25.712 & & & & \\
\hline \multirow{5}{*}{ W380 } & Water & 0.001 & 0.013 & - & - & - & -100 & - \\
\hline & Built-up & 5.621 & 6.935 & 8.647 & 13.931 & 14.428 & +53.83 & +102.83 \\
\hline & Bare Land & 7.730 & 7.224 & 6.353 & 7.232 & 6.761 & -17.81 & +5.27 \\
\hline & Agriculture & 10.229 & 9.926 & 9.282 & 3.511 & 2.939 & -9.26 & -62.00 \\
\hline & Vegetation & 3.424 & 2.907 & 2.723 & 2.332 & 2.877 & -20.45 & +4.50 \\
\hline \multicolumn{2}{|c|}{ Total Area $\left(\mathrm{km}^{2}\right)$} & & & 27.005 & & & & \\
\hline \multirow{5}{*}{ W390 } & Water & 0.175 & 0.145 & - & - & - & -100 & - \\
\hline & Built-up & 9.845 & 14.216 & 16.450 & 20.655 & 23.027 & +67.09 & +66.80 \\
\hline & Bare Land & 4.758 & 11.270 & 12.197 & 13.073 & 8.367 & +156.33 & -80.48 \\
\hline & Agriculture & 19.722 & 11.188 & 11.493 & 5.535 & 6.600 & -41.72 & -24.81 \\
\hline & Vegetation & 7.933 & 5.613 & 2.292 & 3.169 & 4.439 & -71.10 & +27.06 \\
\hline \multicolumn{2}{|c|}{ Total Area $\left(\mathrm{km}^{2}\right)$} & & & 42.432 & & & & \\
\hline \multirow{5}{*}{ W440 } & Water & 0.715 & 0.398 & - & - & - & -100 & - \\
\hline & Built-up & 0.421 & 0.496 & 1.052 & 4.559 & 5.655 & +149.79 & +1092.74 \\
\hline & Bare Land & 14.171 & 16.943 & 21.560 & 20.381 & 18.803 & +52.14 & -19.45 \\
\hline & Agriculture & 28.335 & 25.929 & 20.874 & 18.471 & 17.225 & -26.33 & -12.88 \\
\hline & Vegetation & 0.347 & 0.223 & 0.503 & 0.578 & 2.306 & +44.82 & +518.91 \\
\hline \multicolumn{2}{|c|}{ Total Area $\left(\mathrm{km}^{2}\right)$} & & & 43.988 & & & & \\
\hline \multirow{5}{*}{ W450 } & Water & 0.002 & 0.018 & - & - & - & -100 & - \\
\hline & Built-up & 7.715 & 11.196 & 14.386 & 20.695 & 22.026 & +86.47 & +99.03 \\
\hline & Bare Land & 8.209 & 9.412 & 6.848 & 7.685 & 6.645 & -16.58 & -2.48 \\
\hline & Agriculture & 19.366 & 12.792 & 13.140 & 8.281 & 7.050 & -32.15 & -31.45 \\
\hline & Vegetation & 3.530 & 5.404 & 4.448 & 2.161 & 3.101 & +26.01 & -38.14 \\
\hline \multicolumn{2}{|c|}{ Total Area $\left(\mathrm{km}^{2}\right)$} & & & 38.822 & & & & \\
\hline \multirow{5}{*}{ W480 } & Water & 0.006 & 0.017 & - & - & - & -100 & - \\
\hline & Built-up & 0.412 & 0.412 & 0.501 & 3.074 & 3.984 & +21.62 & +844.98 \\
\hline & Bare Land & 2.728 & 3.442 & 3.759 & 5.422 & 5.020 & +37.81 & +46.22 \\
\hline & Agriculture & 10.135 & 10.704 & 9.620 & 6.254 & 5.592 & -5.08 & -39.75 \\
\hline & Vegetation & 3.032 & 1.739 & 2.433 & 1.563 & 1.717 & -19.77 & -23.60 \\
\hline \multicolumn{2}{|c|}{ Total Area $\left(\mathrm{km}^{2}\right)$} & & & 16.313 & & & & \\
\hline \multirow{5}{*}{ W500 } & Water & 0.167 & 0.022 & - & - & - & -100 & - \\
\hline & Built-up & 0.117 & 0.053 & 0.137 & 1.495 & 1.607 & +16.92 & +1256.92 \\
\hline & Bare Land & 8.689 & 8.331 & 7.939 & 7.928 & 8.351 & -8.63 & +4.74 \\
\hline & Agriculture & 7.570 & 8.710 & 8.875 & 7.691 & 6.380 & +17.24 & -32.96 \\
\hline & Vegetation & 1.278 & 0.704 & 0.869 & 0.706 & 1.481 & -31.96 & +47.90 \\
\hline \multicolumn{2}{|c|}{ Total Area $\left(\mathrm{km}^{2}\right)$} & & & 17.820 & & & & \\
\hline & Water & 0.001 & 0.028 & - & - & - & -100 & - \\
\hline & Built-up & 0.410 & 0.275 & 0.500 & 3.173 & 4.655 & +22.20 & +1014.51 \\
\hline W510 & Bare Land & 25.180 & 23.697 & 22.507 & 21.094 & 17.429 & -10.62 & -20.17 \\
\hline & Agriculture & 24.115 & 27.329 & 27.149 & 25.700 & 23.766 & 12.58 & -14.03 \\
\hline & Vegetation & 2.027 & 0.404 & 1.576 & 1.765 & 5.882 & -22.25 & +212.48 \\
\hline & rea $\left(\mathrm{km}^{2}\right)$ & & & 51.732 & & & & \\
\hline & Water & 0 & 0.120 & - & - & - & 0 & - \\
\hline & Built-up & 0.344 & 0.358 & 0.521 & 1.378 & 1.278 & +51.57 & +220.16 \\
\hline W540 & Bare Land & 9.729 & 8.786 & 9.393 & 10.290 & 8.258 & -3.45 & -11.67 \\
\hline & Agriculture & 18.395 & 19.655 & 18.356 & 16.514 & 17.271 & -0.22 & -5.90 \\
\hline & Vegetation & 0.607 & 0.156 & 0.805 & 0.893 & 2.267 & +32.64 & +241.10 \\
\hline & rea $\left(\mathrm{km}^{2}\right)$ & & & 29.075 & & & & \\
\hline & Water & 0.023 & 0.005 & - & - & - & -100 & - \\
\hline & Built-up & 0.109 & 0.354 & 0.426 & 1.441 & 1.348 & +290.91 & +847.11 \\
\hline W560 & Bare Land & 7.691 & 7.992 & 6.161 & 7.881 & 7.113 & -19.90 & +12.38 \\
\hline & Agriculture & 15.518 & 16.963 & 18.141 & 18.059 & 18.073 & +16.91 & -0.44 \\
\hline & Vegetation & 5.179 & 3.206 & 3.793 & 1.139 & 1.986 & -26.76 & -34.88 \\
\hline
\end{tabular}


Table 6. Cont

\begin{tabular}{|c|c|c|c|c|c|c|c|c|}
\hline \multirow{2}{*}{ Sub-Basi } & \multirow{2}{*}{ LULC } & \multicolumn{5}{|c|}{ Area $\left(\mathbf{k m}^{2}\right)$} & \multicolumn{2}{|c|}{ (\%) Change in LULC } \\
\hline & & 1984 & 1994 & 2004 & 2014 & 2019 & 1984-2004 & 2004-2019 \\
\hline \multicolumn{2}{|c|}{ Total Area $\left(\mathrm{km}^{2}\right)$} & \multicolumn{5}{|c|}{28.520} & & \\
\hline \multirow{5}{*}{ W570 } & Water & 0 & 0 & - & - & - & 0 & - \\
\hline & Built-up & 0.189 & 0.264 & 0.252 & 0.517 & 0.578 & +33.33 & +172.38 \\
\hline & Bare Land & 1.503 & 1.158 & 0.536 & 0.952 & 1.054 & -64.31 & +34.43 \\
\hline & Agriculture & 5.664 & 7.253 & 7.664 & 7.268 & 6.115 & 35.32 & -27.36 \\
\hline & Vegetation & 2.532 & 1.212 & 1.435 & 1.151 & 2.141 & -43.33 & 27.91 \\
\hline \multicolumn{2}{|c|}{ Total Area $\left(\mathrm{km}^{2}\right)$} & & & 9.887 & & & & \\
\hline \multirow{5}{*}{ W590 } & Water & 0 & 0.001 & - & - & - & 0 & - \\
\hline & Built-up & 0.098 & 0.137 & 0.149 & 0.662 & 0.766 & +52.29 & +628.44 \\
\hline & Bare Land & 2.908 & 2.078 & 1.101 & 0.848 & 1.945 & -62.15 & +29.03 \\
\hline & Agriculture & 13.808 & 15.264 & 15.896 & 16.425 & 14.231 & 15.12 & -12.06 \\
\hline & Vegetation & 3.956 & 3.290 & 3.623 & 2.835 & 3.828 & -8.40 & 5.16 \\
\hline \multicolumn{2}{|c|}{ Total Area $\left(\mathrm{km}^{2}\right)$} & & & 20.769 & & & & \\
\hline \multirow{5}{*}{ W620 } & Water & 0.003 & 0.003 & - & - & - & -100 & - \\
\hline & Built-up & 0.408 & 0.499 & 0.717 & 3.166 & 3.498 & +75.94 & +682.12 \\
\hline & Bare Land & 13.628 & 10.655 & 10.617 & 9.240 & 9.427 & -22.09 & -8.74 \\
\hline & Agriculture & 11.525 & 17.570 & 17.003 & 16.593 & 14.267 & 47.52 & -23.74 \\
\hline & Vegetation & 6.710 & 3.547 & 3.936 & 3.273 & 5.081 & -41.34 & 17.08 \\
\hline
\end{tabular}

As a consequence of the LULC transformation, the runoff coefficient for Erbil basin was also changed. The example results of the hydrological modeling of the outflow for $10 \%$ rainfall probability are presented in Figure 6. The hydrological modeling using HEC-HMS showed that in 1984 the runoff coefficient for Erbil basin was only 0.39, in 1994 and 2004 the rate increased to 0.40 and 0.41, respectively, while in 2014 , this rate reached 0.44 , which could be considered as a high rate.

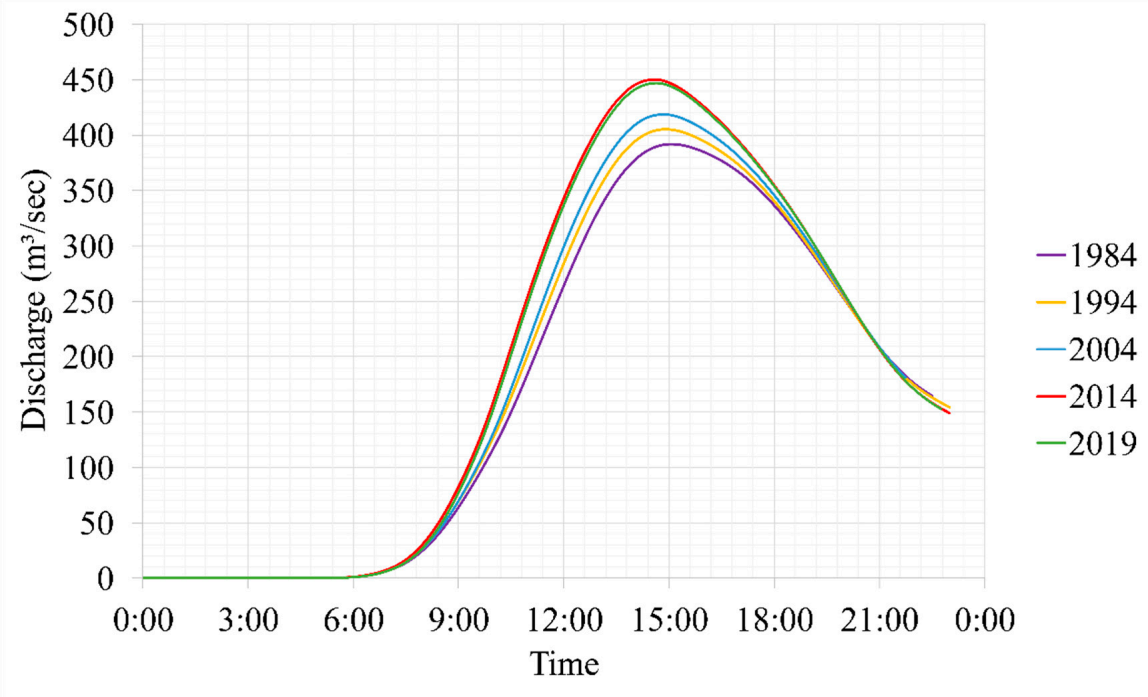

Figure 6. Outflow hydrograph for $\mathrm{p}=10 \%$ rainfall.

As expected, the runoff volume varied in each sub-basin; for instance, there was a considerable LULC change in the sub-basins (W330, W350, W360, W380, W390 and W450). In sub-basin W330, as a consequence of urban development, which was about $2178 \%$ only between 2004 and 2019, the runoff volume increased from 26.58 to $35.42 \mathrm{~mm}$ (Table 7). This revealed that there is a significant impact of urbanization on runoff characteristics. Moreover, Figure 7 and Table 7 show that in all those sub-basins where there was significant urban growth, the runoff coefficient increased as well. The hydrological 
model has not been validated so far due to the lack of outflow measurements in any of the sub-basins in the studied area. The model verification is planned in the next stage of research on urban flash flood risk mitigation in Erbil.

Table 7. Runoff and runoff coefficient in each sub-basin for $\mathrm{p}=10 \%$ rainfall $(71.16 \mathrm{~mm})$.

\begin{tabular}{|c|c|c|c|c|c|c|c|c|c|c|}
\hline \multirow{2}{*}{ Sub-Basin } & \multicolumn{10}{|c|}{ Runoff (mm)/Runoff Coefficient } \\
\hline & \multicolumn{2}{|c|}{1984} & \multicolumn{2}{|c|}{1994} & \multicolumn{2}{|c|}{2004} & \multicolumn{2}{|c|}{2014} & \multicolumn{2}{|c|}{2019} \\
\hline W330 & 26.58 & 0.37 & 27.72 & 0.39 & 30.99 & 0.44 & 35.42 & 0.50 & 35.42 & 0.50 \\
\hline W350 & 27.28 & 0.38 & 27.47 & 0.39 & 28.55 & 0.40 & 31.49 & 0.44 & 31.54 & 0.44 \\
\hline W360 & 31.52 & 0.44 & 33.68 & 0.47 & 34.74 & 0.49 & 37.84 & 0.53 & 38.03 & 0.53 \\
\hline W380 & 32.15 & 0.45 & 32.91 & 0.46 & 33.59 & 0.47 & 36.25 & 0.51 & 36.12 & 0.51 \\
\hline W390 & 31.40 & 0.44 & 33.82 & 0.48 & 35.31 & 0.50 & 36.22 & 0.51 & 36.05 & 0.51 \\
\hline W440 & 30.56 & 0.43 & 30.63 & 0.43 & 30.88 & 0.43 & 31.55 & 0.44 & 31.14 & 0.44 \\
\hline W450 & 30.59 & 0.43 & 31.03 & 0.44 & 32.08 & 0.45 & 35.06 & 0.49 & 35.04 & 0.49 \\
\hline W480 & 29.31 & 0.41 & 30.59 & 0.43 & 30.13 & 0.42 & 32.87 & 0.46 & 33.28 & 0.47 \\
\hline W500 & 28.60 & 0.40 & 28.71 & 0.40 & 28.53 & 0.40 & 29.38 & 0.41 & 28.97 & 0.41 \\
\hline W510 & 31.73 & 0.45 & 32.04 & 0.45 & 31.68 & 0.45 & 32.06 & 0.45 & 31.02 & 0.44 \\
\hline W540 & 30.34 & 0.43 & 30.51 & 0.43 & 30.29 & 0.43 & 30.65 & 0.43 & 29.73 & 0.42 \\
\hline W560 & 28.47 & 0.40 & 29.53 & 0.41 & 29.11 & 0.41 & 30.97 & 0.44 & 30.41 & 0.43 \\
\hline W570 & 28.53 & 0.40 & 30.32 & 0.43 & 29.78 & 0.42 & 30.58 & 0.43 & 29.30 & 0.41 \\
\hline W590 & 22.98 & 0.32 & 23.40 & 0.33 & 23.07 & 0.32 & 23.79 & 0.33 & 23.33 & 0.33 \\
\hline W620 & 29.99 & 0.42 & 31.14 & 0.44 & 31.03 & 0.44 & 31.90 & 0.45 & 31.27 & 0.44 \\
\hline Outlet & 27.40 & 0.39 & 28.26 & 0.40 & 28.97 & 0.41 & 30.97 & 0.44 & 30.66 & 0.43 \\
\hline
\end{tabular}

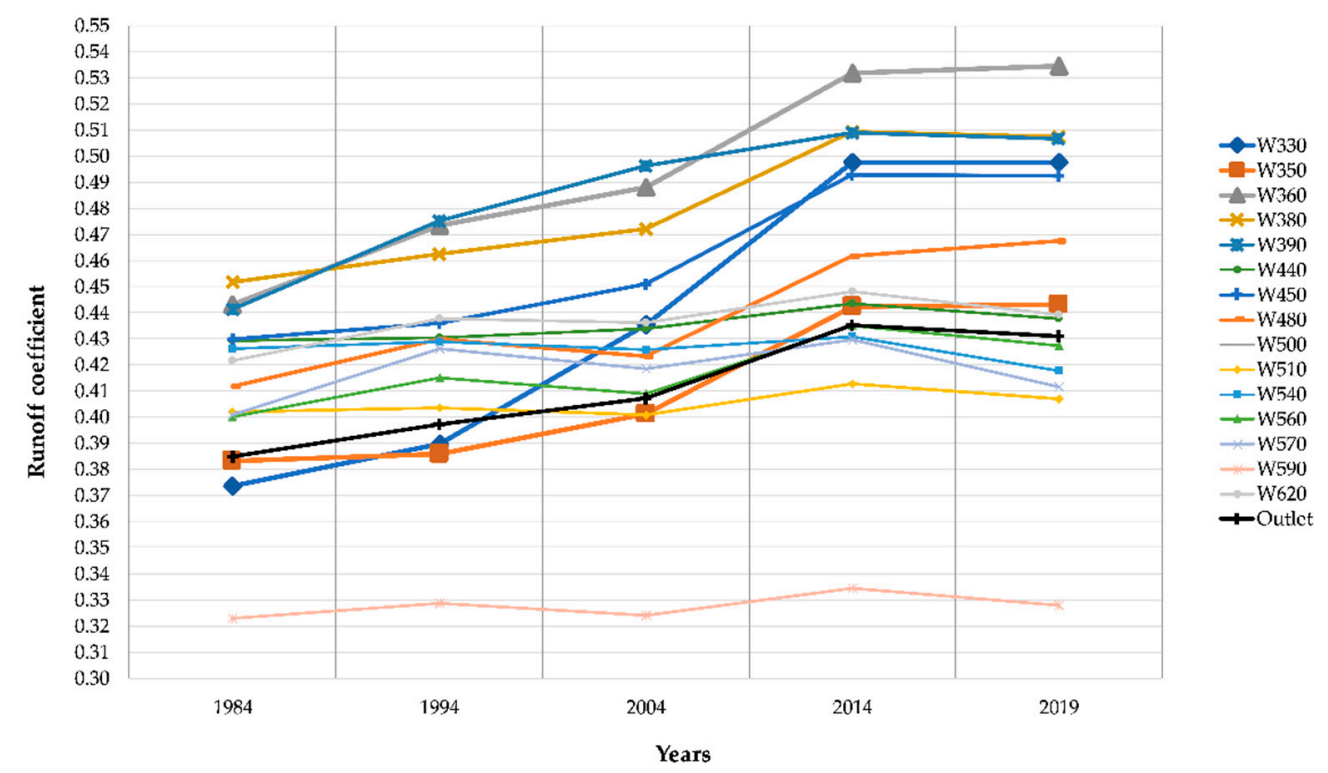

Figure 7. Change in the runoff coefficient in each sub-basin in the study period.

\section{Discussion}

RS data, by employing the maximum likelihood method for image classification, were used to provide detailed information to describe the LULC dynamics around the central district of Erbil Province. Regarding the percentage of the accuracy assessment of the classified images $(85.60 \%)$, this could be considered to be an acceptable classification. A Kappa statistics value of between 0 and 1 for the analysis of classified maps has become the standard for the agreement of maps in practice [65]. The Kappa values for the results of our study and the validation of the visual interpretation classification of five classified images were over 0.79, which means that all maps agree well (a Kappa value between 0.61 and 0.8 is considered to correspond well $[66,67])$. 
Urbanization in Erbil city has witnessed both dramatic changes and shifts in different periods. These changes principally corresponded to legislation factors, in parallel with the political situation, and economic and social determinants over four subsequent periods: (1920-1958), (1958-1991), (1991-2003), (2003-present) [68]. Between 1984 and 2003, Iraq generally and the Kurdistan Region, which was established in 1992, were in a period of slow economic growth, due to the number of wars that happened in this area, such as the Iraq-Iran war (22 September 1980-20 August 1988), Gulf War (2 August 1990-28 February 1991), and Kurdish conflict (1994-1998). However, the Kurdistan Region, and especially Erbil as the capital of the region, witnessed considerable growth and development after 2004. Generally, since 1991, the KRI has been a de facto independent entity making its own regulations and policies, and according to the new constitution, which was prepared in 2005, Iraq is a federal country, with the Kurdistan Region as the only federal state within its borders [69]. Further analysis showed that the increase in built-up areas was about $25 \mathrm{~km}^{2}$ between 1984 and 2004, which nearly equals $1.25 \mathrm{~km}^{2}$ per year. Furthermore, only between 2004 and 2014, the increase in built-up areas was about $63 \mathrm{~km}^{2}$, which is the equivalent of $6.3 \mathrm{~km}^{2}$ per year, which can be considered as very high, indicating rapid urban growth in the city with a spatial and temporal change in land use over only ten years. Oil production and real estate investment caused an economic boom. The population of Erbil Province grew from approximately 95,000 inhabitants in 1965 to about 1.3 million in 2010 [70], recently reaching more than 2 million. Figure 8 shows the evolution of built-up areas from 1984 to 2019. The current study, supported by previous research in this area, demonstrates that increasing urban development in flood plain zones will boost peak discharge, reduce the time to peak, and increase the runoff volume $[2,29,71-74]$.

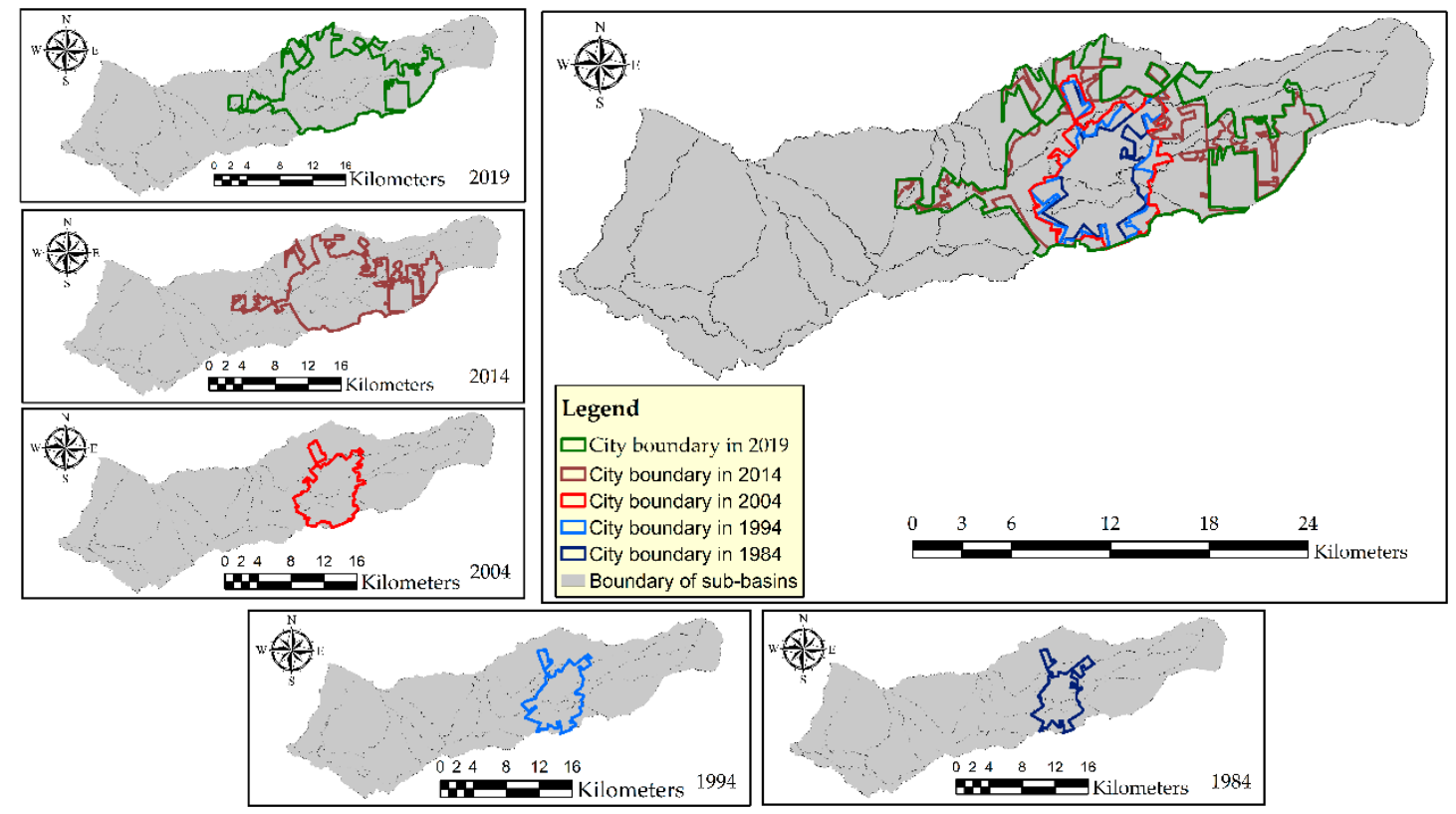

Figure 8. The evolution of built-up areas from 1984 to 2019.

The findings of this study indicate that urbanization resulted in an increased risk of urban flash floods. Another cause of this risk is also the changing characteristics of precipitation as a result of global climate change $[47,63]$. Such floods are dangerous to people and destroy the urban infrastructure due to the overflow of the stormwater drainage system [75] and increase erosion of the land surface [76]. Generally, urban development will not only boost peak discharge but will also elevate the runoff volume and the extent of the flooded zone within a catchment. Because Erbil city center is more or less a flat territory, the flooding will last for a longer time compared to steeper areas, as well as due to the circularity of the main roads around Erbil Citadel, such as Barzani circular street, Kurdistan circular street, Peshawa circular road, $120 \mathrm{~m}$ ring road and the under-construction $150 \mathrm{~m}$ ring road. All 
these mentioned roads cross rivers and streams passing through the city. As a consequence, the routes of most of the rivers and streams have been either blocked or changed to smaller sewer culverts or pipes. This means for urbanized areas, streets, underpasses and low elevation areas, the possibility to be flooded is greater compared to other areas. Erbil center district has suffered from urban flash floods since the 1930s. In the last two decades, the number of flash floods due to heavy rainfalls has increased. Recently, on February 20, 2020, some neighborhoods in the Erbil center district were flooded. According to the meteorological station of the Erbil Directorate of Irrigation, the amount of $24.3 \mathrm{~mm}$ rainfall was measured within six hours. Moreover, the highest rainfall intensity recorded in this episode was $9.8 \mathrm{~mm} /$ hour in the middle of the event. Water accumulated in the expected areas within a short time. The inundation level was more than $25 \mathrm{~cm}$ in some areas, as shown in Figure 9a,b.

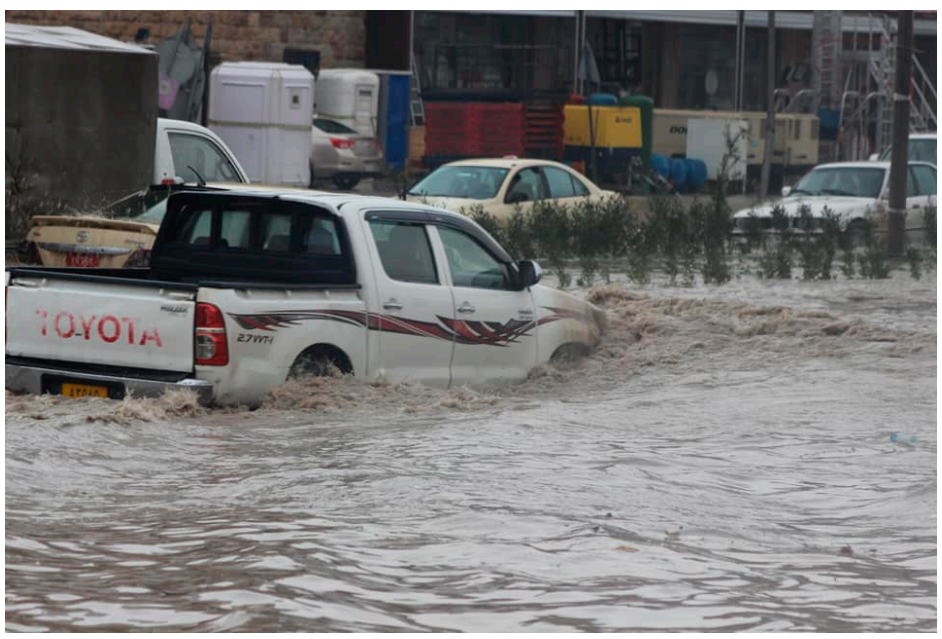

(a)

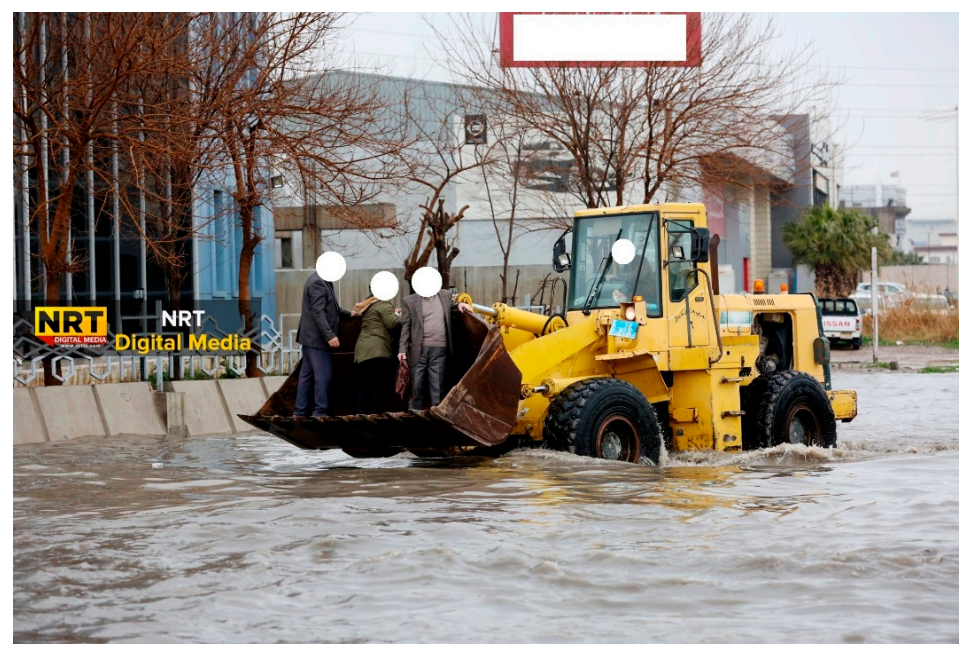

(b)

Figure 9. (a) Difficulty in moving (photo taken by Soran Hassan Jazě). (b) A municipality wheel loader transports officers to a national bank near West Erbil emergency hospital (photo taken from NRT official social media page).

\section{Conclusions}

This study investigated both the dynamic changes in LULC and evolution in the hydrological response in the center of Erbil Province, KRI, from 1984 to 2019 using multispectral satellite data. To sum up our research questions from the introduction section, our outcomes are presented as follows: 
1. The results revealed that between 1984 and 2004, bare land and built-up areas steadily increased, while between 2004 and 2019, built-up areas soared by almost 245\% (from just 55.823 to $136.658 \mathrm{~km}^{2}$ ). Permeable areas like agricultural land and vegetation steadily decreased from 1984 to 2019. Only between 2014 and 2019 did vegetation areas increase, especially in the downstream area of the city. In our opinion, these changes are related to farming types in these areas, and the remote sensing data showed the class as vegetation;

2. Three factors (economic, social and political) influenced the LULC changes in the studied area. For instance, after 2004, the KRI generally, and especially Erbil, enjoyed a decade of prosperity and development due to many factors such as stable security, local and international investment, and the successful implementation of some of the American free market-based developmental policies;

3. The influence of urbanization on the flood peak discharge, runoff volume and runoff coefficient were investigated for the depth of storm rainfall at the probability distribution of $10 \%$, which is equal to $71.16 \mathrm{~mm}$ under different urbanization scenarios. The simulations showed that urban development could considerably aggravate flooding caused by a given storm due to the hindrance of natural drainage and decreasing permeability;

4. As it is obvious in the analysis, parallel to urban development, the runoff volume and peak discharge increased as well. Therefore, the probability of more flash floods in the city is increasing likewise. If the authorities do not take steps related to adopting a new strategy in order to stop urban flash floods, such flash floods will target areas that are denser in urban development and population.

The outcome of this study shows how important remote sensing is for the detection of previous, present and future human activities, in a relatively simple, cheap and easy way. Moreover, without using RS data and GIS techniques, the analysis of LULC in third world countries is somehow difficult or impossible. The results achieved from the study indicate that there is an increase in the runoff peak and volume, which is due to the hydrological response related to urbanization in the city. As a consequence of this, the possibility of flash floods is increased and it becomes a risk to life quality in the studied area, especially in the center of the city. The findings of the study are also important for policymakers and local authorities when deciding how to re-adapt the city to the current situation and plan for future development. In addition, the findings and the prepared LULC scenarios of this study will be useful in the research field on the flash floods mitigation in the studied area.

Author Contributions: Conceptualization, A.M. and M.S.; methodology, A.M. and M.S.; software, A.M.; formal analysis, A.M.; investigation, A.M.; resources, A.M. and M.S.; data curation, A.M.; writing-original draft preparation, A.M. and M.S.; writing-review and editing, M.S. and A.M.; supervision, M.S. All authors have read and agreed to the published version of the manuscript.

Funding: This research received no external funding.

Conflicts of Interest: This research continues the previous study on extreme rainfalls as a cause of urban flash floods and contributes to a PhD thesis. The authors declare no conflict of interest.

\section{References}

1. Du, P.; Liu, P.; Xia, J.; Feng, L.; Liu, S.; Tan, K.; Cheng, L. Remote sensing image interpretation for urban environment analysis: Methods, system and examples. Remote Sens. 2014, 6, 9458-9474. [CrossRef]

2. Hussein, K.; Alkaabi, K.; Ghebreyesus, D.; Liaqat, M.U.; Sharif, H.O. Land use/land cover change along the Eastern Coast of the UAE and its impact on flooding risk. Geomat. Nat. Hazards Risk 2020, 11, 112-130. [CrossRef]

3. Duncan, J.; Stow, D.; Franklin, J.; Hope, A. Assessing the relationship between spectral vegetation indices and shrub cover in the Jornada Basin, New Mexico. Int. J. Remote Sens. 1993, 14, 3395-3416. [CrossRef]

4. Fromard, F.; Vega, C.; Proisy, C. Half a century of dynamic coastal change affecting mangrove shorelines of French Guiana. A case study based on remote sensing data analyses and field surveys. Mar. Geol. 2004, 208, 265-280. [CrossRef] 
5. Muttitanon, W.; Tripathi, N. Land use/land cover changes in the coastal zone of Ban Don Bay, Thailand using Landsat 5 TM data. Int. J. Remote Sens. 2005, 26, 2311-2323. [CrossRef]

6. Rawat, J.; Biswas, V.; Kumar, M. Changes in land use/cover using geospatial techniques: A case study of Ramnagar town area, district Nainital, Uttarakhand, India. Egypt. J. Remote Sens. Space Sci. 2013, 16, 111-117. [CrossRef]

7. Zubair, A.O. Change Detection in Land Use and Land Cover Using Remote Sensing Data and GIS (A Case Study of Ilorin and Its Environs in Kwara State). Available online: https://www.geospatialworld.net/wpcontent/uploads/2016/04/OpeyemiZubair_ThesisDOC.doc (accessed on 19 April 2020).

8. Gautam, N.; Chennaiah, G.C. Land-use and land-cover mapping and change detection in Tripura using satellite LANDSAT data. Int. J. Remote Sens. 1985, 6, 517-528. [CrossRef]

9. König, H.J.; Schuler, J.; Suarma, U.; McNeill, D.; Imbernon, J.; Damayanti, F.; Dalimunthe, S.A.; Uthes, S.; Sartohadi, J.; Helming, K. Assessing the impact of land use policy on urban-rural sustainability using the FoPIA approach in Yogyakarta, Indonesia. Sustainability 2010, 2, 1991-2009. [CrossRef]

10. Swangjang, K.; Iamaram, V. Change of land use patterns in the areas close to the airport development area and some implicating factors. Sustainability 2011, 3, 1517-1530. [CrossRef]

11. Tian, Y.; Yin, K.; Lu, D.; Hua, L.; Zhao, Q.; Wen, M. Examining land use and land cover spatiotemporal change and driving forces in Beijing from 1978 to 2010. Remote Sens. 2014, 6, 10593-10611. [CrossRef]

12. Weng, Q. Land use change analysis in the Zhujiang Delta of China using satellite remote sensing, GIS and stochastic modelling. J. Environ. Manag. 2002, 64, 273-284. [CrossRef] [PubMed]

13. Zhao, Y.; Zhang, K.; Fu, Y.; Zhang, H. Examining land-use/land-cover change in the Lake Dianchi Watershed of the Yunnan-Guizhou Plateau of southwest China with remote sensing and GIS techniques: 1974-2008. Int. J. Environ. Res. Public Health 2012, 9, 3843-3865. [CrossRef] [PubMed]

14. Weng, Q. Thermal infrared remote sensing for urban climate and environmental studies: Methods, applications, and trends. ISPRS J. Photogramm. Remote Sens. 2009, 64, 335-344. [CrossRef]

15. Weng, Q.; Lu, D.; Schubring, J. Estimation of land surface temperature-vegetation abundance relationship for urban heat island studies. Remote Sens. Environ. 2004, 89, 467-483. [CrossRef]

16. Topaloğlu, R.H.; Sertel, E.; Musaoğlu, N. Assessment of classification accuracies of sentinel-2 and landsat-8 data for land cover/use mapping. Int. Arch. Photogramm. Remote Sens. Spat. Inf. Sci. 2016, 41, 1055-1059. [CrossRef]

17. Hansen, M.C.; Loveland, T.R. A review of large area monitoring of land cover change using Landsat data. Remote Sens. Environ. 2012, 122, 66-74. [CrossRef]

18. Masek, J.G.; Huang, C.; Wolfe, R.; Cohen, W.; Hall, F.; Kutler, J.; Nelson, P. North American forest disturbance mapped from a decadal Landsat record. Remote Sens. Environ. 2008, 112, 2914-2926. [CrossRef]

19. Thomas, N.E.; Huang, C.; Goward, S.N.; Powell, S.; Rishmawi, K.; Schleeweis, K.; Hinds, A. Validation of North American forest disturbance dynamics derived from Landsat time series stacks. Remote Sens. Environ. 2011, 115, 19-32. [CrossRef]

20. Hussein, S.O.; Kovács, F.; Tobak, Z.; Abdullah, H.J. Spatial distribution of vegetation cover in Erbil city districts using high-resolution Pléiades satellite image. Acta Geogr. Debrecina Landsc. Environ. 2018, 12, 10-22. [CrossRef]

21. Hamad, R. A remote sensing and GIS-based analysis of urban sprawl in Soran District, Iraqi Kurdistan. SN Appl. Sci. 2020, 2, 24. [CrossRef]

22. Houghton, R.A. Revised estimates of the annual net flux of carbon to the atmosphere from changes in land use and land management 1850-2000. Tellus B 2003, 55, 378-390.

23. Dewan, A.M.; Yamaguchi, Y. Land use and land cover change in Greater Dhaka, Bangladesh: Using remote sensing to promote sustainable urbanization. Appl. Geogr. 2009, 29, 390-401. [CrossRef]

24. Dewan, A.M.; Yamaguchi, Y. Using remote sensing and GIS to detect and monitor land use and land cover change in Dhaka Metropolitan of Bangladesh during 1960-2005. Environ. Monit. Assess. 2009, 150, 237. [CrossRef] [PubMed]

25. Jat, M.K.; Garg, P.K.; Khare, D. Monitoring and modelling of urban sprawl using remote sensing and GIS techniques. Int. J. Appl. Earth Obs. Geoinf. 2008, 10, 26-43. [CrossRef]

26. Mundia, C.N.; Aniya, M. Dynamics of landuse/cover changes and degradation of Nairobi City, Kenya. Land Degrad. Dev. 2006, 17, 97-108. [CrossRef] 
27. Aburas, M.M.; Ho, Y.M.; Ramli, M.F.; Ash'aari, Z.H. Monitoring and assessment of urban growth patterns using spatio-temporal built-up area analysis. Environ. Monit. Assess. 2018, 190, 156. [CrossRef]

28. Ali, J.M.; Marsh, S.H.; Smith, M.J. A comparison between London and Baghdad surface urban heat islands and possible engineering mitigation solutions. Sustain. Cities Soc. 2017, 29, 159-168. [CrossRef]

29. Wałega, A.; Radecki-Pawlik, A.; Cupak, A.; Hathaway, J.; Pukowiec, M. Influence of Changes of Catchment Permeability and Frequency of Rainfall on Critical Storm Duration in an Urbanized Catchment-A Case Study, Cracow, Poland. Water 2019, 11, 2557. [CrossRef]

30. Szydlowski, M. Mathematical modelling of flash floods in natural and urban areas. In Transboundary Floods: Reducing Risks through Flood Management; Springer: Dordrecht, The Netherlands, 2006; pp. 143-153.

31. Zope, P.; Eldho, T.; Jothiprakash, V. Impacts of land use-land cover change and urbanization on flooding: A case study of Oshiwara River Basin in Mumbai, India. Catena 2016, 145, 142-154. [CrossRef]

32. Ali, M.; Khan, S.J.; Aslam, I.; Khan, Z. Simulation of the impacts of land-use change on surface runoff of Lai Nullah Basin in Islamabad, Pakistan. Landsc. Urban Plan. 2011, 102, 271-279. [CrossRef]

33. Miller, S.N.; Kepner, W.G.; Mehaffey, M.H.; Hernandez, M.; Miller, R.C.; Goodrich, D.C.; Kim Devonald, K.; Heggem, D.T.; Miller, W.P. Integrating landscape assessment and hydrologic modeling for land cover change analysis 1. JAWRA J. Am. Water Resour. Assoc. 2002, 38, 915-929. [CrossRef]

34. Sanyal, J.; Densmore, A.; Carboneau, P. Analyzing the effect of land-use/cover changes at sub-catchment levels on downstream flood peaks: A semi-distributed modeling approach with sparse data. Catena 2014, 118, 28-40. [CrossRef]

35. Szpakowski, W.; Szydłowski, M. Evaluating the Catastrophic Rainfall of 14 July 2016 in the Catchment Basin of the Urbanized Strzyza Stream in Gdańsk, Poland. Pol. J. Environ. Stud. 2018, 27, 861-869. [CrossRef]

36. Szydłowski, M.; Mikos-Studnicka, P.; Zima, P.; Weinerowska-Bords, K.; Hakiel, J.; Szawurska, D. Stormwater and snowmelt runoff storage control and flash flood hazard forecasting in the urbanized coastal basin. In Proceedings of the 14th International Symposium Water Management and Hydraulic Engineering WMHE, Brno, Czech Republic, 8-10 September 2015; pp. 141-150.

37. Abdouli, K.A.; Hussein, K.; Ghebreyesus, D.; Sharif, H.O. Coastal Runoff in the United Arab Emirates-The Hazard and Opportunity. Sustainability 2019, 11, 5406. [CrossRef]

38. Ali, P.; Bohloul, A.; Hosein, M. The effect of the land use/cover changes on the floods of the Madarsu Basin of Northeastern Iran. J. Water Resour. Prot. 2010, 2. [CrossRef]

39. Apollonio, C.; Balacco, G.; Novelli, A.; Tarantino, E.; Piccinni, A.F. Land use change impact on flooding areas: The case study of Cervaro Basin (Italy). Sustainability 2016, 8, 996. [CrossRef]

40. Batunacun; Nendel, C.; Hu, Y.; Lakes, T. Land-use change and land degradation on the Mongolian Plateau from 1975 to 2015-A case study from Xilingol, China. Land Degrad. Dev. 2018, 29, 1595-1606. [CrossRef]

41. Kaul, H.A.; Sopan, I. Land use land cover classification and change detection using high resolution temporal satellite data. J. Environ. 2012, 1, 146-152.

42. Superczynski, S.D.; Christopher, S.A. Exploring land use and land cover effects on air quality in Central Alabama using GIS and remote sensing. Remote Sens. 2011, 3, 2552-2567. [CrossRef]

43. Sharif, H.O.; Al-Juaidi, F.H.; Al-Othman, A.; Al-Dousary, I.; Fadda, E.; Jamal-Uddeen, S.; Elhassan, A. Flood hazards in an urbanizing watershed in Riyadh, Saudi Arabia. Geomat. Nat. Hazards Risk 2016, 7, 702-720. [CrossRef]

44. Hameed, H.M. Estimating the effect of urban growth on annual runoff volume using GIS in the Erbil sub-basin of the Kurdistan Region of Iraq. Hydrology 2017, 4, 12. [CrossRef]

45. Nanekely, M.; Scholz, M.; Al-Faraj, F. Strategic framework for sustainable management of drainage systems in semi-arid cities: An Iraqi case study. Water 2016, 8, 406. [CrossRef]

46. Goel, M.K. Runoff Coefficient. In Encyclopedia of Snow, Ice and Glaciers; Singh, V.P., Singh, P., Haritashya, U.K., Eds.; Springer: Dordrecht, The Netherlands, 2011; pp. 952-953.

47. Mustafa, A.M.; Muhammed, H.H.; Szydłowski, M. Extreme rainfalls as a cause of urban flash floods; a case study of the Erbil-Kurdistan region of Iraq. Acta Sci. Pol. Form. Circumiectus 2019, 18, 113-132.

48. Ibrahim, R.I.; Mushatat, S.A.; Abdelmonem, M.G. Erbil. Cities 2015, 49, 14-25. [CrossRef] 
49. Yasin, S. Influence of Modernity Versus Continuity of Architectural Identity on House Facade in Erbil City, Iraq. Available online: https://www.researchgate.net/profile/Salahaddin_Baper2/publication/329337353_ INFLUENCE_OF_MODERNITY_VERSUS_CONTINUITY_OF_ARCHITECTURAL_IDENTITY_ ON_HOUSE_FACADE_IN_ERBIL_CITY_IRAQ/links/5c024af1a6fdcc1b8d4d6bf3/INFLUENCE-OFMODERNITY-VERSUS-CONTINUITY-OF-ARCHITECTURAL-IDENTITY-ON-HOUSE-FACADE-INERBIL-CITY-IRAQ.pdf (accessed on 19 April 2020).

50. Eastman, J. IDRISI Kilimanjaro Guide to GIS and Image Processing. Manual Version. Available online: http: //academic.uprm.edu/ \{\}jchinea/cursos/gis/lectesc/Kilimanjaro\%20Manual.pdf (accessed on 19 April 2020).

51. Bailly, J.; Arnaud, M.; Puech, C. Boosting: A classification method for remote sensing. Int. J. Remote Sens. 2007, 28, 1687-1710. [CrossRef]

52. Currit, N. Development of a remotely sensed, historical land-cover change database for rural Chihuahua, Mexico. Int. J. Appl. Earth Obs. Geoinf. 2005, 7, 232-247. [CrossRef]

53. Jensen, J.R. Thematic information extraction: Pattern recognition. Introd. Digit. Image Process. Remote Sens. Perspect. 2005, 337-406.

54. Liu, X.-H.; Skidmore, A.; Van Oosten, H. Integration of classification methods for improvement of land-cover map accuracy. ISPRS J. Photogramm. Remote Sens. 2002, 56, 257-268. [CrossRef]

55. Dissanayake, D.; Morimoto, T.; Ranagalage, M.; Murayama, Y. Land-use/land-cover changes and their impact on surface urban heat islands: Case study of Kandy City, Sri Lanka. Climate 2019, 7, 99. [CrossRef]

56. Ranagalage, M.; Wang, R.; Gunarathna, M.; Dissanayake, D.; Murayama, Y.; Simwanda, M. Spatial forecasting of the landscape in rapidly urbanizing hill stations of South Asia: A case study of Nuwara Eliya, Sri Lanka (1996-2037). Remote Sens. 2019, 11, 1743. [CrossRef]

57. Scharffenberg, W.A.; Fleming, M.J. Hydrologic Modeling System-HEC-HMS-User's Manual-Version 2.1. Available online: https://www.hec.usace.army.mil/software/hec-hms/documentation/CPD-74A_2001Jan.pdf (accessed on 19 April 2020).

58. Manual, U.U.S. Geospatial Hydrologic Modelling Extension, HEC-GeoHMS, Version 1.1. Available online: https://www.hec.usace.army.mil/software/hec-geohms/documentation/HEC-GeoHMS11.pdf (accessed on 19 April 2020).

59. Ponce, V.M.; Hawkins, R.H. Runoff curve number: Has it reached maturity? J. Hydrol. Eng. 1996, 1, 11-19. [CrossRef]

60. Shrestha, M.N. Spatially distributed hydrological modelling considering land-use changes using remote sensing and GIS. In Proceedings of the Map Asia Conference, Kuala Lumpur, Malaysia, 17-19 July 2003; pp. 1-8.

61. Story, M.; Congalton, R.G. Accuracy assessment: A user's perspective. Photogramm. Eng. Remote Sens. 1986, 52, 397-399.

62. Tung, F.; LeDrew, E. The determination of optimal threshold levels for change detection using various accuracy indexes. Photogramm. Eng. Remote Sens. 1988, 54, 1449-1454.

63. Szpakowski, W.; Szydłowski, M. Probable Rainfall in Gdańsk in View of Climate Change. Acta Sci. Pol. Form. Cir. 2018, 3, 175-183. [CrossRef]

64. KRG. Ministry of planning. In Statistic Year Book; Regional Statistical Office: Erbil, Iraqi; Available online: http://www.krso.net/files/articles/120814020503.pdf (accessed on 19 April 2020).

65. Jiang, D.; Huang, Y.; Zhuang, D.; Zhu, Y.; Xu, X.; Ren, H. A simple semi-automatic approach for land cover classification from multispectral remote sensing imagery. PLOS ONE 2012, 7, e45889. [CrossRef]

66. Blackman, N.J.M.; Koval, J.J. Interval estimation for Cohen's kappa as a measure of agreement. Stat. Med. 2000, 19, 723-741. [CrossRef]

67. Landis, J.R.; Koch, G.G. The measurement of observer agreement for categorical data. Biometrics 1977, 33, 159-174. [CrossRef]

68. Sabr, C. A study on the urban form of Erbil city (the capital of Kurdistan region) as an example of historical and fast growing city. Humanit. Soc. Sci. Rev. CD-ROM 2014, 3, 325-340.

69. Jongerden, J.; Wolters, W.; Dijkxhoorn, Y.; Gür, F.; Öztürk, M. The Politics of Agricultural Development in Iraq and the Kurdistan Region in Iraq (KRI). Sustainability 2019, 11, 5874. [CrossRef]

70. Al-Jameel, A.; Al-Yaqoobi, D.; Sulaiman, W. Spatial configuration of Erbil Citadel: Its potentials for adaptive re-use. In Proceedings of the 10th International Space Syntax Symposium, London, UK, 13-17 July 2015. 
71. Huong, H.T.L.; Pathirana, A. Urbanization and climate change impacts on future urban flooding in Can Tho city, Vietnam. Hydrol. Earth Syst. Sci. 2013, 17, 379. [CrossRef]

72. Nirupama, N.; Simonovic, S.P. Increase of flood risk due to urbanisation: A Canadian example. Nat. Hazards 2007, 40, 25. [CrossRef]

73. Saghafian, B.; Farazjoo, H.; Bozorgy, B.; Yazdandoost, F. Flood intensification due to changes in land use. Water Resour. Manag. 2008, 22, 1051-1067. [CrossRef]

74. Suarez, P.; Anderson, W.; Mahal, V.; Lakshmanan, T. Impacts of flooding and climate change on urban transportation: A systemwide performance assessment of the Boston Metro Area. Transp. Res. Part. D Transp. Environ. 2005, 10, 231-244. [CrossRef]

75. Hakiel, J.; Szydłowski, M. Interaction Between Storm Water Conduit Flow and Overland Flow for Numerical Modelling of Urban Area Inundation. In Hydrodynamic and Mass Transport at Freshwater Aquatic Interfaces: 34th International School of Hydraulics; Rowiński, P., Marion, A., Eds.; Springer International Publishing: Basel, Switzerland, 2016; pp. 23-34.

76. Szydłowski, M. Hydraulic analysis of causes of washout of Gdynia-Orłowo sea-shore during the flood in the Kacza river estuary. Pol. Marit. Res. 2019. [CrossRef]

(C) 2020 by the authors. Licensee MDPI, Basel, Switzerland. This article is an open access article distributed under the terms and conditions of the Creative Commons Attribution (CC BY) license (http://creativecommons.org/licenses/by/4.0/). 